\title{
Petroleum Hydrocarbon Removal from Wastewaters: A Review
}

\author{
Leili Mohammadi ${ }^{1, *}$, Abbas Rahdar ${ }^{2} * *$ (D) Edris Bazrafshan ${ }^{3}$, Hamid Dahmardeh ${ }^{4}$, \\ Md. Abu Bin Hasan Susan ${ }^{5}$ (i) and George Z. Kyzas ${ }^{6, *}$
}

1 PhD of Environmental Health, Infectious Diseases and Tropical Medicine Research Center, Resistant Tuberculosis Institute, Zahedan University of Medical Sciences, Zahedan 9816743463, Iran

2 Department of Physics, University of Zabol, Zabol 98615538, Iran

3 Department of Environmental Health Engineering, School of Health, Torbat Heydariyeh University of Medical Sciences, Torbat Heydariyeh 9516915169, Iran; ed_bazrafshan@yahoo.com

4 Department of Chemistry, National Institute of Technology Rourkela, Sundargarh 769008, India; dr.hamid.dahmardeh@gmail.com

5 Department of Chemistry, University of Dhaka, Dhaka 1000, Bangladesh; susan@du.ac.bd

6 Department of Chemistry, International Hellenic University, Kavala 65404, Greece

* Correspondence: lailimohamadi@gmail.com (L.M.); a.rahdar@uoz.ac.ir (A.R.); kyzas@chem.ihu.gr (G.Z.K.); Tel.: +30-2510-462218 (G.Z.K.)

Received: 8 March 2020; Accepted: 7 April 2020; Published: 10 April 2020

\begin{abstract}
Oil pollutants, due to their toxicity, mutagenicity, and carcinogenicity, are considered a serious threat to human health and the environment. Petroleum hydrocarbons compounds, for instance, benzene, toluene, ethylbenzene, xylene, are among the natural compounds of crude oil and petrol and are often found in surface and underground water as a result of industrial activities, especially the handling of petrochemicals, reservoir leakage or inappropriate waste disposal processes. Methods based on the conventional wastewater treatment processes are not able to effectively eliminate oil compounds, and the high concentrations of these pollutants, as well as active sludge, may affect the activities and normal efficiency of the refinery. The methods of removal should not involve the production of harmful secondary pollutants in addition to wastewater at the level allowed for discharge into the environment. The output of sewage filtration by coagulation and dissolved air flotation (DAF) flocculation can be transferred to a biological reactor for further purification. Advanced coagulation methods such as electrocoagulation and flocculation are more advanced than conventional physical and chemical methods, but the major disadvantages are the production of large quantities of dangerous sludge that is unrecoverable and often repelled. Physical separation methods can be used to isolate large quantities of petroleum compounds, and, in some cases, these compounds can be recycled with a number of processes. The great disadvantage of these methods is the high demand for energy and the high number of blockages and clogging of a number of tools and equipment used in this process. Third-party refinement can further meet the objective of water reuse using methods such as nano-filtration, reverse osmosis, and advanced oxidation. Adsorption is an emergency technology that can be applied using minerals and excellent materials using low-cost materials and adsorbents. By combining the adsorption process with one of the advanced methods, in addition to lower sludge production, the process cost can also be reduced.
\end{abstract}

Keywords: oil compounds; removal methods; adsorption; coagulation; advanced oxidation

\section{Introduction}

Oil is a very valuable resource for production of energy and many chemicals. However, negligence during the stages of extraction, transfer, processing, storage, and consumption can cause environmental 
pollution that is more often severe and irreparable [1]. Multi-ring aromatic hydrocarbons have been identified based on various reports in various sources of groundwater. The United States Environmental Organization has given particular attention to these compounds, due to their toxicity and their carcinogenic potential for humans and various animal species [2]. The connection with industry is also noteworthy (Figure 1) [3].

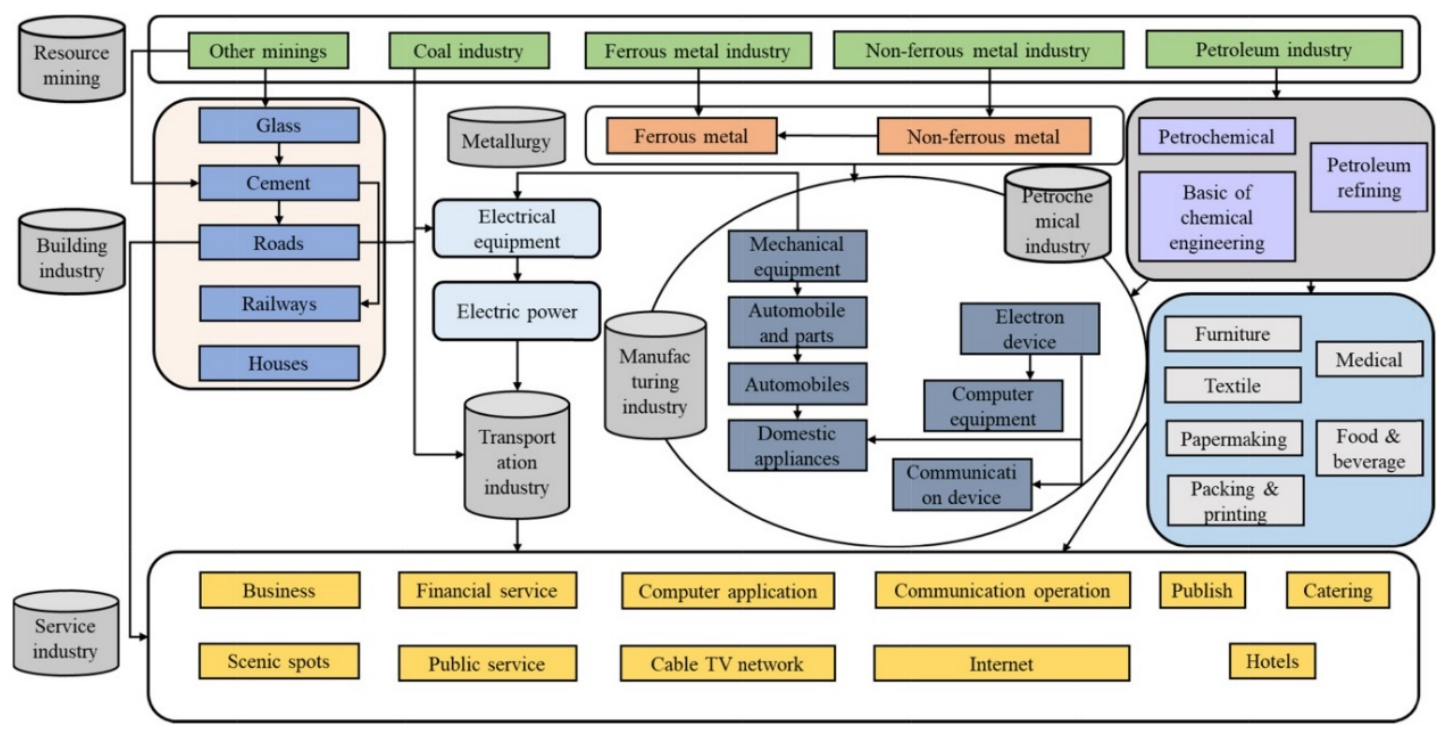

Figure 1. The relationships of the petrochemical industry and other industries [3].

One of the most important sources of emission of these pollutants to water resources is the leakage of storage tanks, extraction, refineries, and distribution stations [4]. The maximum allowable concentration based on the WHO standard for benzene in drinking water is 10 , toluene 700 , ethylbenzene $300 \mu \mathrm{g} / \mathrm{L}$, and for xylene, it is $500 \mu \mathrm{g} / \mathrm{L}$ [5]. The solubility of benzene, toluene, xylene, and ethylbenzene in water is $1780,535,175$, and $152 \mathrm{mg} / \mathrm{L}$, respectively. The molecular structure of benzene, toluene, ethylbenzene, and xylene, commonly known as BTEX materials, and their physicochemical properties are listed in Table 1.

Table 1. Composition of petrochemical hydrocarbons pollutants (BTEX).

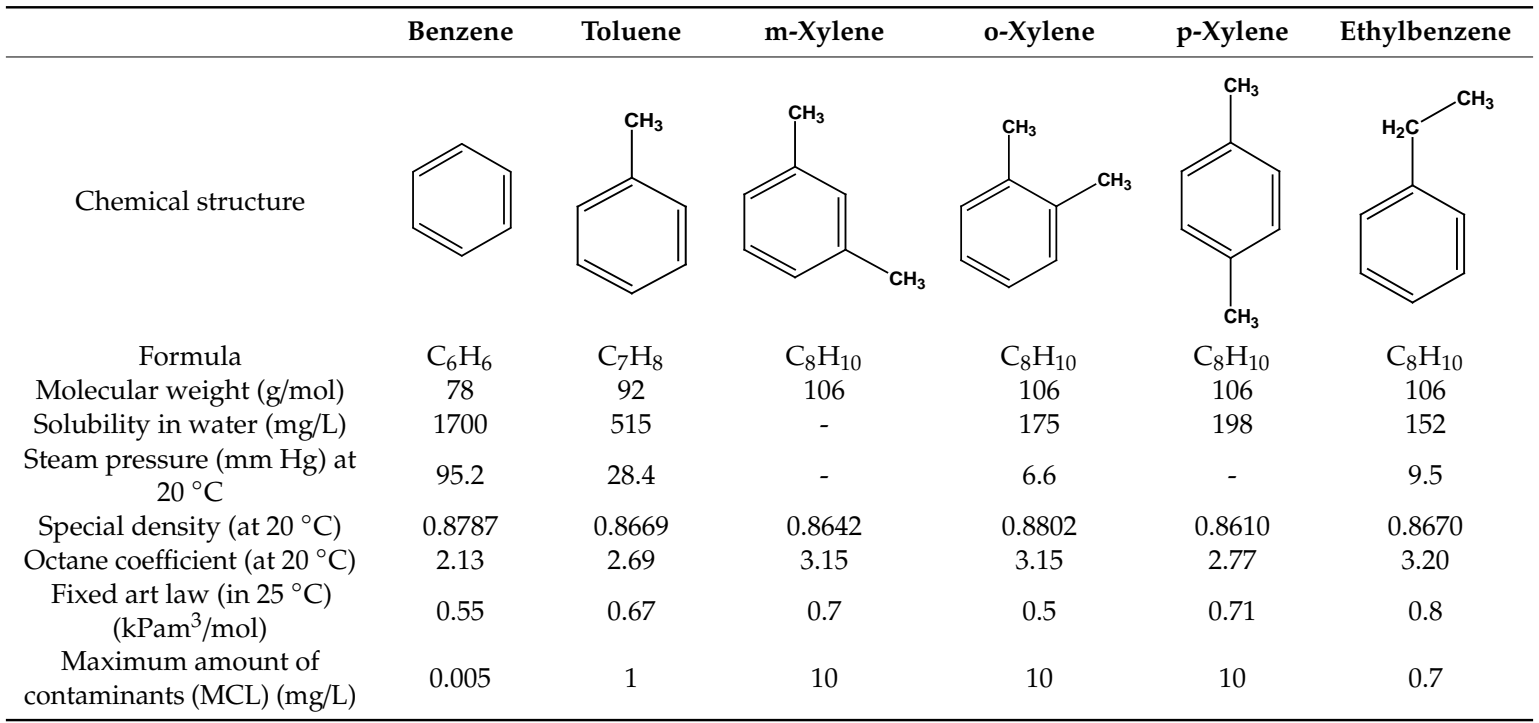


Crude oil is a complex of hundreds of different compounds, often hydrocarbons. Low levels of other elements such as nitrogen $(0 \%$ to $0.5 \%)$, sulfur $(0 \%$ to $6 \%)$, oxygen $(0 \%$ to $3.5 \%)$, and some metals are found to be insignificant in crude oil. The aromatic hydrocarbons (aromatics) are compounds that contain only carbon and hydrogen in their structure, all of which are destructive to the central nervous system. Aromatic hydrocarbons can also cause bone marrow suppression and musculoskeletal malformations [6]. This group of compounds contains benzene and its derivatives, and several condensed benzene rings. Although benzene and most of its compounds are similar, they are not bloated or have a specific aroma. The main source of aromatic hydrocarbons is coal tar. In addition to coal tar, oil sources also extract aromatic compounds such as toluene, benzene, and other compounds with lower boiling points. When hydrogen atoms in the benzene ring are replaced by methyl or ethyl, there are new compounds such as toluene (methylbenzene), xylene (dimethyl benzene), and ethylbenzene. In the case of xylene, there are three types of topical isomers called o-, $\mathrm{m}-$, and p-xylene [7]. The aromatic hydrocarbons have molecular rings, and in general, these compounds are liquid, and they are noticeable in the room temperature of their vapor pressure. This issue, as well as their toxicity, can create significant risks in the workplace. In this group, benzene, toluene, ethylbenzene, styrene, xylene, cumene, and tetralene can be mentioned [8].

Petrochemical hydrocarbons, including BTEX compounds, are known as an indicator for exposure to volatile organic compounds as well as petroleum compounds [9]. Contact with BTEX compounds can occur through eating (using water contaminated with BTEX), inhalation of contaminated air, or adsorption through the skin [10]. Crude-oil-soluble derivatives and refined products include various types of toxic compounds for a wide range of plants and marine organisms. Of these, young, eggs, and larvae of these animals are more sensitive than adult and adult species. In concentrations lower than fatal, petroleum compounds cause physiological and behavioral disorders, and in advanced stages, it may lead to the development of abnormalities among fish and other animals and/or lead to their premature death [11].

Since the petroleum products are made up of different chemicals, their presence in the environment can cause many problems, including the occurrence of disease in cleaning workers, the threat to marine organisms, the risks to pregnant women, neurological disorders, and pulmonary disease. Also, the effects of oil pollution appear in the long-term or short-term [12]. A number of important effects of these pollutants on health are listed in Table 2. One of the important sources of BTEX production in the environment is the combustion of fuel in vehicles and traffic. Other sources include chemical production processes (especially solvents and petroleum products) and coal fuel processes. Inside homes, BTEX sources of human activities include smoking, cooking, heating, cleaning and washing, repairing inside buildings or apartments, disinfecting or spraying homes, using solvents, thawing, and oil paint, and even the furniture and the covering materials of the walls and the floors [13]. Some sources of oil spills are presented in Table 2. Chronic exposure to the BTEX-constituents that enter the body have potentially adverse health effects. These include increased exposure to benign fatal leukemia, central nervous system dysfunction (headache, dizziness, loss of balance and muscle control), adverse effects in the blood, liver, and kidney accumulation due to exposure to BTEX [14].

One of the main sources of BTEX contamination is gasoline leakage as a result of poor and incomplete storage of underground tankers. From other large sources, surface spill and pipe leakage can be mentioned. Upon the arrival of BTEX in the environment, BTEX turns into steam; some of these compounds are dissolved in water, and either stick to soil particles or biodegrade [15]. Evaporation occurs when steam is allowed to move from liquid to air. Evaporation of BTEX compounds in gasoline occurs when gasoline is pumped into the car (when its odor is ingested). This natural process can occur inside the pores of the soil. BTEX can also dissolve into water and thus move underground. 
Table 2. Sources and health effects of petrochemical hydrocarbons pollutants $[11,17,18]$.

\begin{tabular}{|c|c|c|c|c|c|}
\hline \multirow[b]{2}{*}{ Representatives } & \multicolumn{3}{|c|}{ IDLH * } & \multirow[b]{2}{*}{ Sources } & \multirow[b]{2}{*}{ Health Effects } \\
\hline & $\begin{array}{l}\text { Australian and New Zealand } \\
\text { Environmental Protection } \\
\text { Regulations (ppb) }\end{array}$ & $\begin{array}{l}\text { American National } \\
\text { Drinking Water } \\
\text { Standards (ppb) }\end{array}$ & $\begin{array}{l}\text { WHO Drinking } \\
\text { Water Regulations } \\
\text { (ppb) }\end{array}$ & & \\
\hline Benzene & 600 & 5 & 10 & \multirow{2}{*}{$\begin{array}{c}\text { Petroleum products } \\
\text { Incomplete combustion of } \\
\text { liquid fuels }\end{array}$} & Carcinogen \\
\hline Toluene & 180 & 1000 & 700 & & Damage the ozone layer \\
\hline Ethylbenzene & 50 & 700 & 300 & Adhesives Lacquers & $\begin{array}{l}\text { Produce photochemical smog, } \\
\text { and pose mutagenic hazards }\end{array}$ \\
\hline Xylene & 200 & 1000 & 500 & $\begin{array}{l}\text { Chemical industry, coal tar } \\
\text { and oil, leak in oceans, forest } \\
\text { fire }\end{array}$ & $\begin{array}{l}\text { Neurological disorders, } \\
\text { kidney and liver, skin } \\
\text { problems }\end{array}$ \\
\hline
\end{tabular}

* IDLH (immediately dangerous to life or health) from the National Institute of Occupational Safety and Health. 
BTEX can stick to soil particles. This chemical movement occurs more slowly in groundwater, and in the presence of sufficient oxygen, the BTEX compounds can be slowly decomposed. Contact with BTEX can be made by swallowing using BTEX inhalation (contact with BTEX in the air) or absorbing through the pores of the skin. BTEX inhalation can occur when the gas is pumped or washed out and washed with water contaminated with BTEX. The adsorption through the skin can be caused by pouring gasoline on the skin or bathing in contaminated water. Extremely high contact with gasoline and other substances containing BTEX with the skin causes sensitization, irritation, and depression of the central nervous system and effects on the respiratory system. These degrees of contamination are unlikely due to drinking water contaminated with these compounds, but it can be increased due to occupational exposure to these compounds [15]. Among the BTEX materials, the highest percentage is related to benzene. This substance is very reactive and very volatile [16].

Although preventing contamination has always been the best solution, the rapid and appropriate response to the environmental impact of oil spills requires adequate knowledge of the various methods of collecting and purifying contaminants. The cost of collecting pollution is different depending on the type of oil hydrocarbons, the amount and severity of contamination, the coordinates and geographic, economic, physical and biological characteristics of the site, the conditions of the air and sea, the accident time, the efficiency and the type of collection method. Due to the acute and chronic toxic effects of this combination and according to sewage drainage standards, removal of this compound before entering the environment is essential.

\section{Environmental Problems/Scenarios/Fate}

To better understand the environmental impact of petroleum hydrocarbons, it is necessary to briefly refer to the fate of petroleum on environmental systems (Figure 2). A variety of processes occur when petroleum products of any kind (e.g., crude oil, gasoline) are released into the environment. These can be physical abiotic processes or biological through interaction with microorganisms and metabolic pathways. The following are abiotic reactions contributing to the breakdown or movement of various compounds and hydrocarbons found in petroleum products. The fastest physical process is the evaporation of light compounds. The speed and efficiency of this can be influenced by environmental factors such as temperature, wind velocity, water turbulence, or surface characteristics [19].

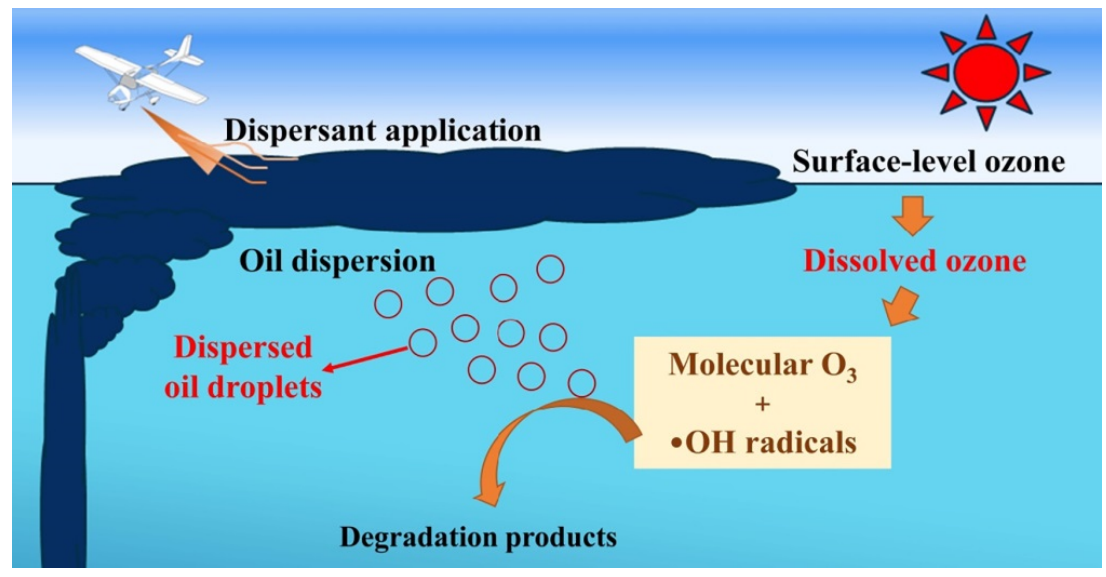

Figure 2. The fate of petroleum hydrocarbons in water/sea. Reprinted with permission from Elsevier [20].

This is often a key process in the initial stages of petroleum release and has been a major factor in the removal of volatile components of petroleum during large scale spills. Soon after initial petroleum release, lighter or shorter chain hydrocarbons can lose large proportions of their mass to evaporation, as much as $99 \%$ or more for light alkanes such as propane, butane, and pentane [21]. Photolytic breakdown of hydrocarbons, especially PAHs and BTEX compounds found in petroleum, is another method of petroleum weathering in the environment. By interacting with the aromatic structure 
pi-bonded system consisting of delocalized electrons, light can be absorbed to promote a higher energy state. This excited state can facilitate the breakdown of the compound, leading to the degradation of light-absorbing compounds within the petroleum mixture. The dissolution of petroleum hydrocarbons can occur based on the solubility of the compounds involved. Solubilities of these hydrocarbons vary based on specific properties, including molecular size, structure, and polarity. Low molecular weight aromatics are typically among the most soluble compounds within a petroleum mixture [19]. Other compounds such as alkanes are non-polar and thus largely hydrophobic and highly unlikely to dissolve in water. Chemical agents are often used in instances of spills to increase the solubility of petroleum compounds. Surfactants and dispersants can create hydrophilic aggregates or emulsions in water, breaking down the petroleum particle sizes and diluting the hazardous compounds and aiding the potential for biodegradation [22]). Many petroleum hydrocarbons have a high affinity for organic matter due to their hydrophobicity. As such, they can easily adsorb to organic matter and will preferentially bind to soil and sediments. Once sorbed, these eight compounds are difficult to remove and can persist for many years before degradation [23]. One underlying factor contributing to the persistence of sorbed petroleum hydrocarbons is the limited surface area, causing a lack of bioavailability for biodegradation and limited access to the physical processes that may otherwise contribute to their breakdown or dilution. In cases where large volumes of petroleum reach shorelines, such as large spills, the presence of petroleum hydrocarbons can increase erosion due to interference with the soil/sediment matrix [24]. Once sorbed, transport of these hydrophobic contaminants can occur through erosion or sediment or soil mixing. Erosion of coastal sediments has been known to redistribute petroleum hydrocarbons into the water column, allowing for transport and potentially re-exposure to plants or marine life.

A special environmental scenario must be done for the case of soil (Figure 3). Though social and economic development largely depend on petroleum hydrocarbons as a dominant source of energy, it has caused a huge area of contamination and relevant adverse effects [25]. The contamination of petroleum hydrocarbons disseminates from soil and water to human health. Petroleum hydrocarbon contamination on soil petroleum hydrocarbon contamination of soil is a widespread global environmental concern.

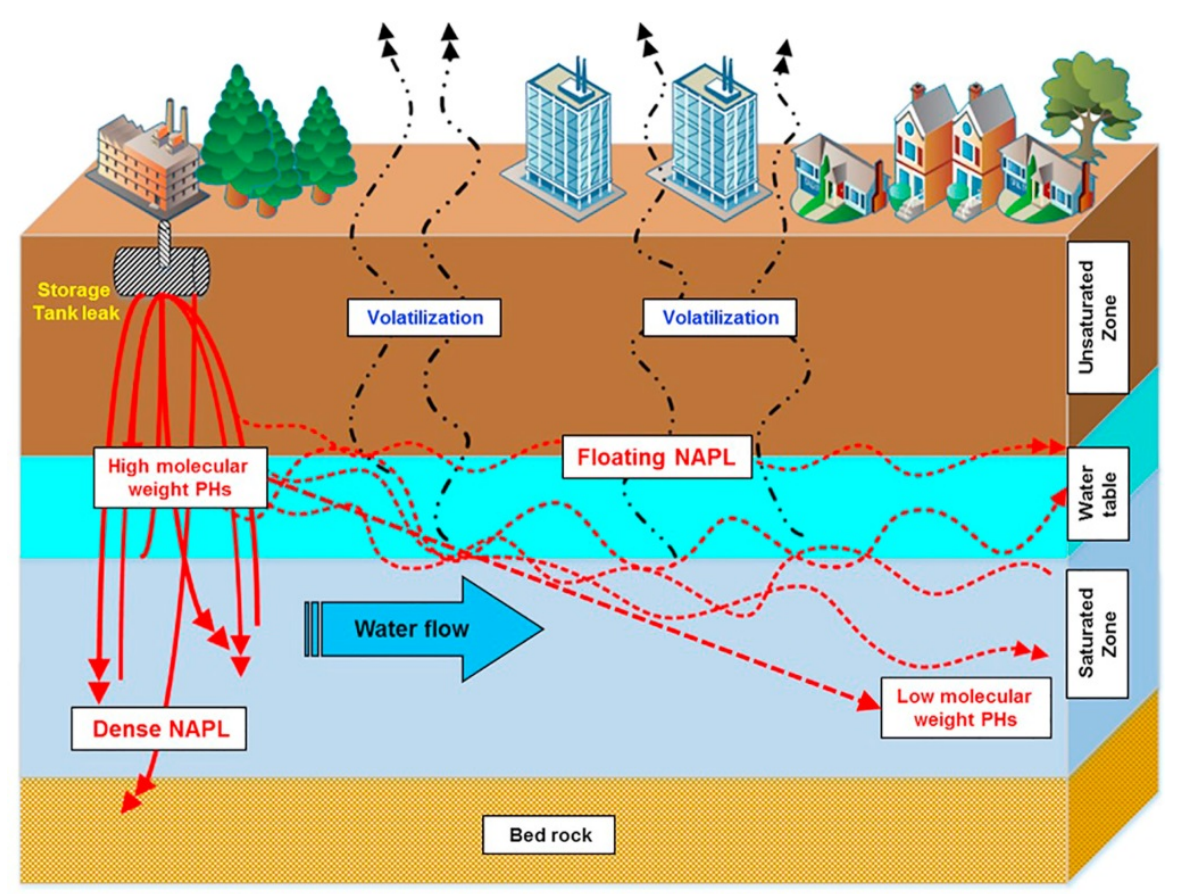

Figure 3. The fate of petroleum hydrocarbons in soil. Reprinted with permission taken by Elsevier [26]. 
Oil and fuel spills in soil are among the most extensive and environmentally damaging pollution problems as it is threatening to human health and ecosystems, especially in cold regions. Biochemical and physicochemical properties of soil are deteriorated by refinery products, and it also limits the growth and development of plants. Water and oxygen deficits, as well as to shortage of available forms of nitrogen and phosphorus, are the main changes in soil properties due to contamination with petroleum-derived substances. Petroleum-hydrocarbon-contaminated soil causes organic pollution of underground water, which restricts its use and causes economic loss, environmental problems, and decreases the agricultural productivity of the soil. Microorganisms, plants, animals, and humans are facing vulnerable situations because of the toxicity of petroleum hydrocarbons. Soil enzymes are one of the important biotic components which are responsible for soil biochemical reactions. Petroleum hydrocarbon has adverse effects on soil enzyme activities [25]. Diesel oil has a much stronger inhibitory effect on nitrification than petrol. Diesel oil can cause chronic or acute effects in the plants. Interference in the hydric relations of the plants is caused by diesel oil pollution. Petroleum hydrocarbon released into the sea, normally during transportation, leading to the pollution of several sites, and can eventually reach the coasts. Oil spills ranging from low-level discharges to catastrophic accidents threaten coastal environments; large spills commonly are followed by clean-up efforts, but complete containment is rare. As the solubility of petroleum hydrocarbon in water is generally low, certain fractions of it float in water and form thin surface films, which will facilitate agglomeration of particles and natural organic matter, and impact oxygen transfer. Other heavier fractions will accumulate in the sediment at the bottom of the water, which may affect bottom-feeding fish and organisms [25].

\section{Removal and Purification Methods}

The latest methods of removing and eliminating oil pollution from the sea include aeration; adsorption processes with the help of activated carbon and natural and synthetic adsorbents; oxidation by some oxidants; the use of laser technology; the use of dispersants; adsorption and separation of water surface by various types of adsorbents, especially adsorbents prepared using nanotechnology; evaporation of petroleum compounds using vacuum techniques; physical separation by means of foaming; conversion of oil pollution to other compounds by methods such as photo-oxidation as well as biological methods [12].

A high set-up and exploitation cost, the need for skilled personnel to set up and operate, the lack of rapid adaptation of microorganisms to remove these compounds, the presence of electron receptors, and the production of secondary toxic compounds have limited the use of these methods [27]. A summary of the methods used to remove oil compounds is presented in Table 3. 
Table 3. Technologies used for the removal of petrochemical hydrocarbons pollutants.

\begin{tabular}{|c|c|c|c|c|c|c|c|c|}
\hline Methods & Reaction Conditions & Efficiency & $\begin{array}{c}\text { Market } \\
\text { Sales }\end{array}$ & Reuse & $\begin{array}{c}\text { Waste } \\
\text { Generation }\end{array}$ & $\begin{array}{c}\text { Energy } \\
\text { Consumption }\end{array}$ & $\begin{array}{c}\text { BTEX } \\
\text { Concentration }\end{array}$ & Ref. \\
\hline $\begin{array}{l}\text { Thermal } \\
\text { incineration }\end{array}$ & $\begin{array}{c}\text { Fixed-bed reactor; catalyst, } \\
\mathrm{MnO}_{\mathrm{x}} / \gamma-\mathrm{Al}_{2} \mathrm{O}_{3} \text {; temperature, } \\
443-873 \mathrm{~K} . \text { Rotary kiln } \\
\text { incinerator; temperature, } \\
\sim 1273 \mathrm{~K}\end{array}$ & $>99 \%$ (40 min) & High & No & $\mathrm{CO}, \mathrm{NO}_{\mathrm{x}}$ & Moderate & $20-25 \%$ & {$[28,29]$} \\
\hline $\begin{array}{l}\text { Fenton } \\
\text { Oxidation }\end{array}$ & $\begin{array}{c}\text { Wash water of ion-exchange } \\
\text { resin, } \mathrm{pH} 3-4 ; \\
\mathrm{CH}_{2} \mathrm{O}_{2}=1200 \mathrm{mg} / \mathrm{L}, \mathrm{CFe}^{2+}= \\
300 \mathrm{mg} / \mathrm{L} \text {. TCE-contaminated } \\
\text { groundwater, } \mathrm{pH} 5.4, \mathrm{ORP}=465 \\
\text { mv; } 10 \mathrm{~g} / \mathrm{L} \text { basic oxygen furnace, } \\
1.0 \mathrm{~g} / \mathrm{L} \text { of } \mathrm{H}_{2} \mathrm{O}_{2}\end{array}$ & $\begin{array}{l}100 \% \text { and } 87 \% \\
\text { removal of } 1,2-D C A \\
\text { and TOC in } 90 \mathrm{~min}, \\
\text { respectively. } 81 \% \\
(1 \mathrm{~h}) .\end{array}$ & - & No & $\begin{array}{l}\mathrm{CO}_{2} ; \mathrm{Cl}^{-} ; \mathrm{Fe}^{3+} \\
\mathrm{CO}_{2} ; \mathrm{Cl}^{-} ; \mathrm{CE} \\
\quad \text { DCE. }\end{array}$ & High & - & {$[30,31]$} \\
\hline Condensation & & Moderate & High & Yes & - & High & $>5000 \mathrm{ppm}$ & [29] \\
\hline $\begin{array}{l}\text { Biological } \\
\text { degradation }\end{array}$ & & $100 \%$ ( 7 months $)$ & Low & No & $\begin{array}{l}\text { Acetaldehyde, } \\
\text { Propanol, } \\
\text { Acetone }\end{array}$ & Low & $<5000$ ppm & [32] \\
\hline $\begin{array}{c}\text { Adsorption } \\
\text { process }\end{array}$ & $\begin{array}{c}\text { Activated carbon/photocatalytic } \\
\text { oxidation hybrid system }\end{array}$ & $>90 \%$ & High & Yes & Spent adsorbent & Moderate & $700-10,000$ ppm & {$[33-43]$} \\
\hline $\begin{array}{l}\text { Ozonation } \\
\text { process }\end{array}$ & $\begin{array}{l}\text { Contaminated soil; flushing } \\
\text { solvent, acetic acid; ozone } \\
\text { concentration, } 17 \pm 2 \mathrm{mg} / \mathrm{L} \text {; } \\
\text { temperature, } 20 \pm 2{ }^{\circ} \mathrm{C} \text {. }\end{array}$ & $100 \%(2 \mathrm{~h})$ & High & & - & High & $10 \%$ and $25 \%$ & {$[44]$} \\
\hline Plasma catalysis & $\begin{array}{c}\text { A hybrid pulsed power corona } \\
\text { reactor with adjustable energy } \\
\text { density }\end{array}$ & $74-81 \%$ & High & No & $\begin{array}{c}\text { Formic acid, } \\
\text { Carboxylic } \\
\text { acids, } \mathrm{NO}_{x}, \mathrm{O}_{3}\end{array}$ & High & 70-100 ppm & [45] \\
\hline $\begin{array}{l}\text { Photocatalytic } \\
\text { oxidation }\end{array}$ & $\begin{array}{c}\text { Gas conditions; gas flow } \\
200 \mathrm{~mL} / \mathrm{min} \text { for } 30 \mathrm{~min} \text {; infrared } \\
\text { cell; } \mathrm{UV} \text { irradiation, } 150 \mathrm{~W} \\
\text { Xenon lamp; catalyst, } \mathrm{N} \text {-doped } \\
\mathrm{TiO}_{2} \text {. Gas conditions in } \mathrm{O}_{2} \\
\text { stream; low-pressure }\end{array}$ & $100 \%$ (5 min) & Low-moderate & No & $\begin{array}{l}\text { Strong oxidant } \\
\mathrm{OH} \bullet \text { radicals }\end{array}$ & Moderate & - & {$[46,47]$} \\
\hline
\end{tabular}


Table 3. Cont.

\begin{tabular}{|c|c|c|c|c|c|c|c|c|}
\hline Methods & Reaction Conditions & Efficiency & $\begin{array}{c}\text { Market } \\
\text { Sales }\end{array}$ & Reuse & $\begin{array}{c}\text { Waste } \\
\text { Generation }\end{array}$ & $\begin{array}{c}\text { Energy } \\
\text { Consumption }\end{array}$ & $\begin{array}{c}\text { BTEX } \\
\text { Concentration }\end{array}$ & Ref. \\
\hline $\begin{array}{c}\text { Catalytic } \\
\text { ozonation } \\
\text { process (COP) }\end{array}$ & $\begin{array}{l}\text { ozone was generated using a } \\
\text { commercial ozone generator } \\
\text { marketed as an air purifier, and } \\
\text { particle measurements were } \\
\text { recorded before, during, and } \\
\text { after the release of terpenes from } \\
\text { a pine oil-based cleaning } \\
\text { product. }\end{array}$ & $100 \%(2 \mathrm{~h})$ & High & No & $\begin{array}{c}\text { Secondary } \\
\text { organic aerosols }\end{array}$ & High & $200-10$ & [48] \\
\hline $\begin{array}{l}\text { Membrane } \\
\text { separation }\end{array}$ & & - & Low & Yes & $\begin{array}{l}\text { Clogged } \\
\text { membranes }\end{array}$ & High & $<25 \%$ & {$[28,29]$} \\
\hline $\begin{array}{l}\text { Coagulation/ } \\
\text { flocculation } \\
\text { with } \\
\text { sedimentation }\end{array}$ & & 87 (as COD)- $98.8 \%$ & & No & - & Moderate & >105 ppm & {$[49,50]$} \\
\hline $\begin{array}{l}\text { Flocculation } \\
\text { with DAF }\end{array}$ & $\begin{array}{l}\text { A pot trial was carried out to } \\
\text { investigate the effect of biochar } \\
\text { produced from green waste by } \\
\text { pyrolysis on the yield of radish } \\
\text { (Raphanussativus var. Long } \\
\text { Scarlet) and the soil quality of an } \\
\text { Alfisol }\end{array}$ & $\begin{array}{l}90 \% \text {, at higher rates } \\
\text { of biochar } \\
\text { application } \\
(>50 \mathrm{t} / \mathrm{ha})\end{array}$ & & No & - & Moderate & $>150 \mathrm{ppm}$ & [51] \\
\hline $\begin{array}{l}\text { Coagulation } \\
\text { with foam } \\
\text { separation }\end{array}$ & & $95 \%$ & & No & - & High & $0.9-58$ & [52] \\
\hline $\begin{array}{l}\text { Coagulation/ } \\
\text { flocculation } \\
\text { with MFC }\end{array}$ & $\begin{array}{l}\text { screening aerobic, heterotrophic } \\
\text { marine bacteria for production of } \\
\text { volatile organic compounds }\end{array}$ & $94 \%$ & & & & High & $50-100$ & {$[53]$} \\
\hline $\begin{array}{l}\text { Demulsification } \\
\text { with } \\
\text { centrifugation }\end{array}$ & $\begin{array}{l}\text { Catalytic combustion of } \\
\text { acetaldehyde was investigated } \\
\text { on various oxide-supported } \\
\text { metal catalysts prepared by } \\
\text { impregnation method }\end{array}$ & & & & & & & {$[54]$} \\
\hline
\end{tabular}


Table 3. Cont.

\begin{tabular}{|c|c|c|c|c|c|c|c|c|}
\hline Methods & Reaction Conditions & Efficiency & $\begin{array}{l}\text { Market } \\
\text { Sales }\end{array}$ & Reuse & $\begin{array}{c}\text { Waste } \\
\text { Generation }\end{array}$ & $\begin{array}{c}\text { Energy } \\
\text { Consumption }\end{array}$ & $\begin{array}{c}\text { BTEX } \\
\text { Concentration }\end{array}$ & Ref. \\
\hline Electrocoagulation & $\begin{array}{l}\text { Adsorption of phenol and its } \\
\text { derivatives on activated } \\
\text { carbons }\end{array}$ & $99 \%$ (as turbidity) & & & & & 80 & {$[49,55]$} \\
\hline Centrifugation & $\begin{array}{l}\text { The implications for } \\
\text { greenhouse gas emissions of } \\
\text { optimizing a slow } \\
\text { pyrolysis-based bioenergy } \\
\text { system for Biochar and energy } \\
\text { production rather than solely } \\
\text { for energy production }\end{array}$ & $68.83 \%$ & & & & & & [56] \\
\hline $\begin{array}{l}\text { Coalescence on } \\
\text { granular bed }\end{array}$ & $\begin{array}{l}\text { Practical approach for } \\
\text { adsorption modeling }\end{array}$ & $71-99 \%$ & & & & & $4-500$ & [57-59] \\
\hline $\begin{array}{l}\text { Membrane } \\
\text { separation }\end{array}$ & $\begin{array}{l}\text { The adsorption onto activated } \\
\text { carbon }\end{array}$ & $97-99 \%$ & & & & & & [60-63] \\
\hline
\end{tabular}




\subsection{Canvas}

The use of canvas is now commonly used to capture and seal leakage of oil. These canvases are designed to prevent floating oil from escaping the surface of the water. One type of canvas, called a canopy fence, consists of a PVC barrier that is fitted underneath the polyethylene floats and is provided with apertures for holding the barrier at the bottom. In some of its types, 6-foot-long hinges are used, with a total length of 50-100-feet in length [27].

\subsection{Chemicals}

One of the methods for concentrating oil is the use of chemicals at contaminated water levels that reduces the rate of oil release and causes oil returns at the level of the oil mass. This method is used in real-world oil spills only in calm water [64].

\subsection{Microorganisms}

Many studies have shown that microorganisms (fungi, bacteria, and yeasts) are the main factors in the decomposition of pollutant molecules, including hydrocarbons, in aquatic and terrestrial environments. Selective microorganisms should be able to accept hydrocarbons as substrates (primary). These microorganisms must have the ability to synthesize enzymes with the ability to accelerate the digestive process of hydrocarbons, and, in addition, harmful products produced by them are not harmful to the environment. Nevertheless, no microorganism alone is able to completely disperse crude oil [65]. Crude oil distillation involves a series of forward chain reactions in which specific microorganisms initiate an initial attack on petroleum compounds. This process results in the production of intermediate compounds that will result in the use of a different class of microorganisms. Local native microorganisms, or LMOs, in the ground and underground waters of oil regions that have become accustomed to these conditions over time can use carbon from pollutants as sources of energy. These germs convert the pollutants into final products (carbon dioxide and water).

\subsection{Adsorption Method}

Sorbents, materials, or mixtures of insoluble materials are used to recover fluids during adsorption, physical attachment, or both [66-76]. Adsorbents must be absorbent of oil compounds and also waterproof [77]. Although they may be used as the only cleaning method for small leaks, adsorbents are often used to remove the final oil trap. Also, the benefits of using adsorbents are to limit the speed of the playback of the layer and help clean it. Debris can be divided into three basic groups: organic, natural, and combined organic. Natural organic adsorbents include carbon monoxide, nitrogen, dry grass, sawdust, corn wood, feathers, and other products, mainly carbon-readable. Organic adsorbents can absorb between 3 and 15 times the weight of their oil, but their use also has some disadvantages. Some organic adsorbents tend to absorb water as much as absorbing oil. This causes the absorbent to drown.

Many organic adsorbents lose particles such as sawdust, which is difficult to collect after being spread over the surface of the water [77]. Natural mineral adsorbents can absorb oil from 4 to 20 times their weight. Mineral absorbers, like organic adsorbents, are inexpensive and readily available in large amounts. These types of adsorbents are not used on the surface of the water. Combined absorbents include human-made materials that resemble plastics, such as polyurethane, polyethylene, and polypropylene, which are designed to absorb fluids on their surface (such as sponges). Other compound absorbents include shrink-bonded polymers and rubber materials, which absorb fluids on their solid structure, causing the swelling of absorbent materials.

Most composite adsorbents can absorb oil up to 70 times their weight. The properties of both absorbent and oil types should be considered when selecting adsorbents to clean up leakages. Oil adsorption with light petroleum products is faster. Also, the oils with thicker layers are more effective at attaching surfaces. Lightweight oil with less viscosity than the heavier and more viscosity type is 
easier to handle during retrieval of sealing materials, which results in secondary contamination [77]. Johnson and coworkers suggested the potential of using linen fiber to clean up oil spills (Johnson et al. (1973)). Further studies were performed by Cloud and Choi on milkweed. In this paper, the canopy was investigated, and it was found that in the case of high viscosity oil adsorption, it is comparable to polypropylene. Hemp flax and milk, without requiring any process on them, have hydrothermal characteristics due to the presence of wax on their surface, and these have been used as adsorbents in research on the cleaning of oil spills on water and drought [78].

In a report presented by Schrader, the adsorption capacity of mineral, organic, and synthetic adsorbents was compared. According to the results of this study, inorganic adsorbents had a minimum adsorption capacity, while synthetic adsorbents had the highest adsorption capacity. Adsorbents such as canopy also had medium to high adsorption capacity [79]. In another article, the adsorption capacities of various synthetic and natural absorbents were studied [80]. According to this study, natural absorbents such as plant milk, silk fiber, cotton, linen, and wool showed higher adsorption capacities than synthetic adsorbents such as polyester, polypropylene, nylon 6, and nylon 66 . By studying the adsorption mechanism by scanning electron microscopy, it was determined that the milk absorbs oil by capillary action, and the wool uses surface adsorption [80]. Methods based on phase separation or surface adsorption, such as activated carbon, cannot completely eliminate the effects of oil contaminants in water, but their use can be very useful in reducing the contamination of oil in water [81]. These methods do not eliminate the organic matter of the water completely [81].

\subsection{Soil Vapor Extraction (SVE)}

BTEX compounds are volatile and, analogous to the volatile organic compounds (VOCs), can be easily removed by soil vapor extraction (SVE) if the conditions are suitable $[82,83]$. The SVE does not work well in wet or otherwise impermeable oil $[83,84]$ and is considerably slower in cold than in warm conditions $[84,85]$.

\subsection{Plasma Treatment Method}

Various gas-phase electric discharge methods, also known as plasma treatments, are currently the subject of intense development. Electric discharge plasma is defined as a mixture of free moving electrons and positively charged ions [86]. Non-thermal plasma is a source of gas-phase free radicals $(\mathrm{O}, \mathrm{OH}$, and $\mathrm{H})$ and other active species, which are useful for destroying pollutants. Reactive species in non-thermal plasma, such as $\mathrm{OH}$ radicals, $\mathrm{O}_{3}$ molecules, and $\mathrm{O}$ atoms, can react with odorous and toxic gases and vapors and convert them into non-odorous and non-toxic molecules. Plasma can be generated in a medium between two spatially separated electrodes, where a high AC voltage (10-30 kV) is applied for a very short time (1-10 ms) [87]. Plasma may be generated by electric discharges of various types: dielectric barrier discharge (DBD), arc, gliding arc, spatial, glow, pulsed, or streamer discharge, with or without dielectric barriers [88]. The main advantages of low-temperature plasma technologies in BTEX abatement are their relatively low energy consumption and generally moderate cost [89]. Several studies on BTEX removal, side product analysis, and degradation mechanisms by non-thermal plasma (NTP) have been reported over the past few years. Satoh et al. explored the effect of $\mathrm{O}_{2}$ proportion in carrier gas on the removal of benzene by different manners of discharge. The results show that at low oxygen concentration, the byproducts are primarily $\mathrm{C}_{2} \mathrm{H}_{2}, \mathrm{HCN}, \mathrm{NO}$, and $\mathrm{HCOOH}$, while only $\mathrm{HCOOH}$ is found at high oxygen concentrations [90]. Stefan et al. investigated the degradation of cyclohexene and BTEX in an NTP air purifying system, and the degradation efficiency order of benzene $(<x y l e n e(3 \%) \approx$ ethylbenzene $<$ toluene $(11 \%) \approx$ cyclohexene) was found [91].

\subsection{Photocatalytic Oxidation}

Among AOPs, heterogeneous photocatalytic oxidation, which involves the acceleration of a photoreaction in the presence of a semiconductor catalyst, has proved to be of utmost interest due to its efficiency in degrading recalcitrant organic compounds [92,93]. Developed in the 1970s, 
heterogeneous photocatalytic oxidation has been provided considerable attention from the scientific research community. During the past two decades, numerous studies have been carried out on the application of heterogeneous photocatalytic oxidation processes with an aim to decompose and mineralize recalcitrant organic compounds. Photocatalysts are the class of compounds that generate electron-hole pairs on coming in contact with or on the absorption of light quanta, leading to the chemical transformation of substrates that comes in contact with them and regenerate them. These substances are invariably semiconductors. Semiconductor heterogeneous photocatalysis has enormous potential to treat organic contaminants in water and air. Many semiconductors have been studied for the degradation of petrochemical compounds. Several semiconductors $\left(\mathrm{TiO}_{2}, \mathrm{ZnO}, \mathrm{Fe}_{2} \mathrm{O}_{3}, \mathrm{CdS}, \mathrm{ZnS}\right)$ can act as photocatalysts [93]. However, $\mathrm{TiO}_{2}$ has been most widely and universally studied because of its high reactivity, reduced toxicity, chemical stability, lower costs, its ability to break down organic pollutants, resulting in complete mineralization.

The available literature revealed that $\mathrm{TiO}_{2}$, along with other semiconductors/nanomaterials, has been widely studied for the degradation processes in visible and UV light irradiation. In addition, most of the degradation studies were carried out at laboratory scale under UV light. The uses of alternative light sources such as LEDs are promising initiatives for the reduction in power consumption. It is imperative to develop more efficient techniques in which solar energy is used for photocatalysis processes. Only $5 \%$ of solar radiation is used for catalysis processes. Also, various studies reported that the intermediates are sometimes more toxic than the original compound. Therefore, intermediates or end products of photocatalytic degradation may prove harmful to various organisms in the environment. However, $\mathrm{TiO}_{2}$ is only responsive to the $\mathrm{UV}$ region due to its large band gap $(3.2 \mathrm{eV})$. To expand the application of $\mathrm{TiO}_{2}$, the doping of metals were investigated to enhance the photo-response of $\mathrm{TiO}_{2}$ toward the visible region [94]. Some indicative examples are given in following paragraphs.

There are many examples in the literature reporting the doping of $\mathrm{TiO} 2$ with various metals for BTEX degradation. Ce-doped $\mathrm{TiO}_{2}$ nanostructures $(\mathrm{CeT})$ with different amounts of $\mathrm{Ce}(0.5,0.75,1.0,1.5$, and $2.0 \mathrm{wt} \%$ ) were synthesized using a sonochemical processing method by Lee et al. [94]. The prepared CeT exhibited significantly improved photocatalytic performance towards the degradation of toluene and o-xylene, which was much higher than that observed for pure $\mathrm{TiO} 2$ and commercial P25 TiO2. Particularly, photocatalytic degradation efficiencies by the prepared CeT catalysts increased remarkably in the case of o-xylene (up to $99.4 \%$ ) compared to toluene (up to $49.1 \%$ ).

Another important study by Laokiat et al. investigated the synthesis and evaluation of transition metal ( $\mathrm{Fe}, \mathrm{V}$, and $\mathrm{W}$ )-doped $\mathrm{TiO}_{2}$ via the solvothermal technique and immobilized onto fiberglass cloth (FGC) for uses in photocatalytic decomposition of gaseous volatile organic compounds-benzene, toluene, ethylbenzene and xylene (BTEX)—under visible light [95]. Results were compared to that of the standard commercial pure TiO2 (P25)-coated FGC. All doped samples exhibit higher visible light catalytic activity than the pure TiO2. The V-doped sample shows the highest photocatalytic activity, followed by the W- and Fe-doped samples. The UV-vis diffuse reflectance spectra reveal that the $\mathrm{V}$-doped sample has the highest visible light absorption, followed by the $\mathrm{W}$ - and Fe-doped samples.

\subsection{Nanostructure Materials}

Researchers at Rice University in Texas discovered that nanotechnologies could be used to clean the environment from pollutants, particularly the leakage of oil in groundwater. The researchers showed that nanoparticles of thin metal and carbon can trap droplets of water, causing these droplets (over 10 million drops) to be stacked together and form small spherical packages. The researchers also discovered that ultraviolet light and magnetic fields can be used to orient the nanoparticles to form packages and release their cargo. The researchers in the study found multi-faceted nanowires that are similar to nanoscale structures. These nanowires, when incorporated into a mixture of water and oil, can separate oil from water. The researchers are investigating the nanoscale coatings covered with zirconium particles for this purpose. A group of researchers has made a nanomat that can be used as a tool to clean up oil spills and other organic materials. Nanomaterial has a structure like paper and can 
be used in the near future as an important tool in the oil industry and its related industries. The new technology involves a new membrane that can absorb particles and spots up to 20 times its weight. Additionally, reusing it without damaging its structure is another notable feature of this nanomat. This has been invented while more than 200,000 tons of oil has recently been distributed on the surface of the world, and so far, there has been no effective way of collecting these stains [96].

\subsection{Advanced and Chemical Oxidation}

The conventional oxidation treatment involves the addition of an oxidizing agent to water or a solution containing contaminants. After such simple chemical oxidation, the pollutants are decomposed and removed. Usually, chemical oxidation in wastewater treatment means adding oxidizing agents such as ozone, hydrogen peroxide, permanganate, chlorine dioxide, chlorine $\left(\mathrm{Cl}_{2}, \mathrm{HOCl}\right)$, and oxygen to the sewage to change the chemical composition of one or more pollutants [97].

Also, some of the most important applications of oxidation in sewage management have been to reduce the amount of bacteria and sewage viruses in order to control the odor and eliminate ammonia and solutes. Chemical oxidation is also effective for the removal of odorous compounds such as sulfides and mercaptans. In addition to the aforementioned uses of chemical oxidation, in order to improve the biological purification ability of organic or non-biodegradable organic compounds, the removal of inhibitory effects of some organic and inorganic materials on microbial growth, reducing or eliminating the toxicity of certain organic and inorganic materials on microbial growth and aquatic plants are used to remove BOD, COD, ammonium, and resistant organic compounds [97]. Types of chemical oxidation treatment methods are purification by conventional oxidation and purification by advanced oxidation methods.

Chemical oxidation with ozone $\left(\mathrm{O}_{3}\right)$ to remediate the soil has been gaining incremental attention over the past few decades. The strong oxidizing power of ozone should overcome the heavy fraction's residual problem by making them more soluble (thus more bioavailable) and simpler in structure (more biodegradable). Ozone and the hydroxyl radical $(\mathrm{OH} \bullet)$, which can be produced form ozone, can react with all types of hydrocarbons and produce hydrophilic compounds, but through different mechanisms. The dominant oxidation pathways for $\mathrm{OH} \bullet$ are hydrogen abstraction and $\mathrm{OH} \bullet$ addition. In contrast, ozone attacks hydrocarbons via molecule addition, which leads to bond breaking [98]. Chen et al. [99] evaluated how gas-phase $\mathrm{O}_{3}$ interacts with residual petroleum hydrocarbons in soil. Total petroleum hydrocarbons (TPH) were $18 \pm 0.6 \mathrm{~g} / \mathrm{kg}$ soil, and TPH carbon constituted $\sim 40 \%$ of the dichloromethane-extractable carbon (DeOC) in the soil. At the benchmark dose of $3.4 \mathrm{~kg} \mathrm{O} / \mathrm{kg}$ initial $\mathrm{TPH}, \mathrm{TPH}$ carbon was reduced by nearly $6 \mathrm{~g} \mathrm{C} / \mathrm{kg}$ soil (40\%), which was accompanied by an increase of about $4 \mathrm{gC} / \mathrm{kg}$ soil in dissolved organic carbon (DOC) and a 4-fold increase in 5-day biochemical oxygen demand $\left(\mathrm{BOD}_{5}\right)$. Disrupting gas channeling in the soil improved mass transport of $\mathrm{O}_{3}$ to TPH bound to soil and increased TPH removal. Ozonation resulted in two measurable alterations of the composition of the organic carbon. First, part of DeOC was converted to DOC ( 4.1 g C/kg soil), 75\% of which was not extractable by dichloromethane. Second, the DeOC containing saturates, aromatics, resins, and asphaltenes (SARA) was partially oxidized, resulting in a decline in saturates and aromatics, but an increase in resins and asphaltenes. Ozone attack on resins, asphaltenes, and soil organic matter led to the production of $\mathrm{NO}_{3}{ }^{-}, \mathrm{SO}_{4}{ }^{2-}$, and $\mathrm{PO}_{4}{ }^{3-}$. The results illuminate the mechanisms by which ozone gas interacted with the weathered petroleum residuals in soil to generate soluble and biodegradable products. Also, hydrogen peroxide concentration plays an important role in the reduction of BTEX. The excess amount of $\mathrm{H}_{2} \mathrm{O}_{2}$ acts as hydroxyl radical's scavenger $\left(\mathrm{HO}_{2}\right)$, and as a strong oxidizer, hydrogen peroxide breaks down BTEX into by-products $\left(\mathrm{H}_{2} \mathrm{O}_{2}+\mathrm{O}_{2} \bullet \rightarrow \bullet \mathrm{OH}+\mathrm{OH}^{-}+\mathrm{O}_{2}\right)$ [100].

Permanganates are crystalline solids well known as oxidizing agents. They are available as sodium and potassium permanganates. It is easily handled, readily available, strong and versatile oxidizing agent with a relative oxidizing power of 1.24. Their versatility in reacting with a wide range of organic compounds over a wide range of $\mathrm{pH}$ is attributable to the variable oxidation state of manganese in the reactions at different $\mathrm{pHs}$ [101]. At very acidic $\mathrm{pHs}$, i.e, at $\mathrm{pHs}$ less than 3.5, they have 
been found to react as $\mathrm{MnO}_{4}{ }^{-}+8 \mathrm{H}^{+}+5 \mathrm{e}^{-} \mathrm{Mn}^{2+}+4 \mathrm{H}_{2} \mathrm{O}$. In this, manganese has been reduced from manganite (VII) to manganite (II). An important contribution was published by Bajagain et al. [102], who studied the permanganate pretreatment to degrade petroleum hydrocarbons in unsaturated soil in combination with subsequent bioaugmentation. The pretreatment of diesel-contaminated unsaturated soil with 0.5 -pore-volume (5\%) potassium permanganate (PP) by solution pouring and foam spraying (with a surfactant) achieved the total petroleum hydrocarbon (TPH) removal efficiencies of $37 \%$ and $72.1 \%$, respectively. The PP foam, when coupled with bioaugmentation foam, further degraded the $\mathrm{TPH}$ to a final concentration of $438 \mathrm{mg} / \mathrm{kg}$ (92.1\% total reduction). This experiment was conducted without soil mixing or disturbance. The relatively high TPH removal efficiency achieved by the PP-bioaugmentation serial foam application may be attributed to an increase in soil $\mathrm{pH}$ caused by the PP and effective infiltration of the remediation agent by foaming. The applied PP foam increased the $\mathrm{pH}$ of the acidic soil, thus enhancing microbial activity. Furthermore, $94 \%$ of the group of relatively persistent hydrocarbons $\left(\mathrm{C}_{18}-\mathrm{C}_{22}\right)$ was removed by PP-bioaugmentation, as verified by chromatogram peaks. The results revealed that PP can degrade soil TPH and significantly enhance the biodegradation rate in unsaturated diesel-contaminated soil when combined with bioaugmentation foam.

Advanced oxidation processes (ozone, ozone, hydrogen peroxide, ozone/ultraviolet, hydrogen peroxide/ultraviolet) are suitable alternatives for decomposing organic biodegradable organic waste from conventional wastewater treatment $[103,104]$. The advanced oxidation process has significant advantages (such as the lack of high levels of sludge production) compared to conventional filtration methods. This method usually produces hydroxyl radicals at ambient temperature, which unintentionally attacks all organic and inorganic pollutants in the sewage system. Since advanced oxidation processes are expensive and have high operating costs, in recent years, a new approach to these processes, called catalytic ozonation processes (COP), has been considered [105-107]. Recently, various metals such as iron, aluminum, zinc, chromium, and copper have been used as catalysts to enhance the efficiency of advanced oxidation processes [108].

One of the benefits of advanced oxidation is that the processes are generally able to completely destroy specific substances. Therefore, using a biological method as a final treatment will complete the process. Heterogeneous photocatalysts, along with semiconducting processes, extinction, Fenton and sonolysis and similar processes are more efficient than other processes such as wet oxidation and electro dialysis. However, most studies have been conducted with the model of aqueous solutions and surface water (including rivers and lakes), while less attention has been paid to the actual wastewater from wastewater treatment plants or effluent from industrial units [109].

At this point, it is important to mention the Fenton (or the photo-Fenton oxidation process). Fenton's reaction is a non-expensive and environmentally friendly oxidation method, which was discovered by Fenton in 1894 when he strongly improved tartaric acid oxidation with the use of ferrous ion $\left(\mathrm{Fe}^{2+}\right)$ and $\mathrm{H}_{2} \mathrm{O}_{2}$ [110]. This process is widely used in wastewater treatment. Fenton's reagent is a solution of $\mathrm{H}_{2} \mathrm{O}_{2}$ and ferrous ions with a complex mechanism, which can be simplified by the following reactions [111,112]:

(a) $\mathrm{H}_{2} \mathrm{O}_{2}+\mathrm{Fe}^{2+} \rightarrow \mathrm{Fe}^{3+}+\mathrm{OH}^{-}+\mathrm{HO}^{\bullet}$

(b) Organic matter $+\mathrm{HO}^{\bullet} \rightarrow$ Oxidation int ermidiates

(c) Oxidation int ermidiates $+\mathrm{HO}^{\circ} \rightarrow \mathrm{CO}_{2}+\mathrm{H}_{2} \mathrm{O}$

(d) $\mathrm{H}_{2} \mathrm{O}_{2}+\mathrm{HO}^{\circ} \rightarrow \mathrm{H}_{2} \mathrm{O}+\mathrm{HO}_{2}^{\circ}$

(e) $\mathrm{Fe}^{2+}+\mathrm{HO}^{\circ} \rightarrow \mathrm{Fe}^{3+}+\mathrm{OH}^{-}$

(f) $\mathrm{HO}^{\bullet}+\mathrm{HO}^{\bullet} \rightarrow \mathrm{H}_{2} \mathrm{O}_{2}$

(g) $\mathrm{Fe}^{3+}+\mathrm{H}_{2} \mathrm{O}_{2} \leftrightarrow \mathrm{Fe}^{\text {III }}\left(\mathrm{HO}_{2}\right)^{2+}+\mathrm{H}^{+}$

(h) $\mathrm{Fe}^{\mathrm{III}}\left(\mathrm{HO}_{2}\right)^{2+} \rightarrow \mathrm{Fe}^{2+}+\mathrm{HO}_{2}$. 
Briefly, the reaction between ferrous ions and $\mathrm{H}_{2} \mathrm{O}_{2}$ produces hydroxyl radicals with high oxidative power (a) that attack the organic compounds present in the water (b). Unfortunately, some parallel reactions occur $(\mathrm{d}-\mathrm{f})$, and so the hydroxyl radicals are not only consumed to degrade the organic matter but also to produce other radicals, with less oxidative power, or other species (scavenging effect of $\mathrm{HO}^{\bullet}$ ). In addition, this leads to the undesired consumption of $\mathrm{H}_{2} \mathrm{O}_{2}(\mathrm{~d})$. On the other hand, reaction ( $\mathrm{g}$ ) and (h) indicate generation of $\mathrm{Fe}^{2+}$ by the reaction between $\mathrm{H}_{2} \mathrm{O}_{2}$ and $\mathrm{Fe}^{3+}$ (Fenton-like process); this way, ferrous ion is restored, acting as a catalyst in the overall process [111,112].

Contrary to the materials mentioned for the function of the advanced oxidation process, if the concentration of carbonate and bicarbonate ions is significant in the environment, it can react with hydroxyl ions and reduce the efficiency of the advanced oxidation process. As the $\mathrm{pH}$ increases, carbonate ions and bicarbonate ions increase significantly, reducing the process efficiency [113]. Conventional wastewater treatment methods have been incapable of meeting the new standards and regulations of the environment. Therefore, methods such as oxidation using cavitation and ultrasound [114], and hybrid methods such as sonication, followed by wet-acid oxidation (SONIWO), sonoid-photochemical degradation [115], and removal by sono-electrochemical and others [116] are used.

\subsection{Coagulation and Electrocoagulation}

Electrocoagulation is an electrochemical process that has proven to be effective for wastewater treatment and water purification. Despite the high efficiency and environmental-friendly potential of the process, high capital and operating costs have made its application on an industrial scale not so promising. Also, the major disadvantages of electrical and chemical coagulation are the production of large quantities of dangerous sludge that are unrecoverable and often repelled. The elemental composition of petroleum sludge is $\mathrm{N}, \mathrm{P}, \mathrm{K}, \mathrm{Fe}, \mathrm{Cu}, \mathrm{Fe}, \mathrm{Ca}, \mathrm{Mg}, \mathrm{Cd}, \mathrm{Cr}, \mathrm{Zn}, \mathrm{Pb}$ [117,118]. Petroleum sludge is a complex mixture containing different quantities of waste oil, wastewater, sand, and mineral matter. Petroleum industries are responsible for the generation of large quantities of sludge, which is a major source of environmental pollution. Oily sludges are hazardous wastes according to the Environment Protection Act and Hazardous Wastes Handling Rules. These sludges cannot be disposed of as landfill even if they are de-oiled unless they are totally remediated. Sludges generated by petroleum industries accumulate in crude oil tanks, refinery products tanks, desalters, and elsewhere during oil production and processing. The sludges containing recoverable oil less than $40 \%$ are considered as low oil content sludges. These sludges have to be treated and made harmless before disposal $[117,119]$.

The efficacy of the electrocoagulation process (ECP) is usually evaluated for the treatment of petroleum-contaminated groundwater and quantified as the total petroleum hydrocarbon (TPH) removed by electrode materials (majorly aluminum, iron, and steel). The maximum TPH removal has been achieved using steel-iron as the anode-cathode electrode arrangement. In most cases, batch and continuous experiments showed that the ECP could be efficient in eliminating TPH from water and thus may be a promising technique for treating petroleum-contaminated groundwater [118]. An indicative example of the above is a published study, based on which electrocoagulation process was used for the removal of turbidity from petrochemical wastewater. The batch experiments were carried out by varying the values of current density, $\mathrm{NaCl}$ concentration and electrolysis time and maximum turbidity removal efficiency was $97.43 \%$ [120]. In addition, treatment of gas refinery oily wastewater by electrocoagulation using aluminum electrodes was investigated in another study and gas chromatographic analysis of raw and treated wastewater revealed that most normal hydrocarbons (nearly 99\%) were removed during the electrocoagulation process [121].

Verma et al. investigated coagulation-flocculation as a pretreatment process for the treatment of purified terephthalic acid (PTA) wastewater [122]. The effect of various inorganic and organic coagulants on the treatment of wastewater collected from a flow equalization tank of an effluent treatment plant was studied. The settling and filtration characteristics of the sludge were also studied. 
The jar tests revealed that the wastewater was best treated when $3000 \mathrm{mg} / \mathrm{L}$ of ferric chloride was dosed at $\mathrm{pH}$ 5.6. At optimum conditions, the COD of the wastewater was reduced by $75.5 \%$. The results of the gravity filtration of the treated wastewater showed that the addition of cationic polyacrylamide $(175 \mathrm{mg} / \mathrm{L})$ to ferric chloride coagulation improved the filtration characteristics and reduced the specific cake resistance.

Another important contribution is a study published by El-Ashtoukhy et al. [123] who explored the possibility of using electrocoagulation to remove phenolic compounds from oil refinery waste effluent using an electrochemical reactor with a fixed bed anode made of randomly oriented Al raschig rings packed in a perforated plastic basket located above the horizontal cathode. The study revealed that the optimum conditions for the removal of phenolic compounds were achieved at current density $=8.59 \mathrm{~mA} / \mathrm{cm}^{2}, \mathrm{pH}=7, \mathrm{NaCl}$ concentration $=1 \mathrm{~g} / \mathrm{L}$, and temperature of $25^{\circ} \mathrm{C}$. Remarkable removal of $100 \%$ of phenol compound after $2 \mathrm{~h}$ was achieved for $3 \mathrm{mg} / \mathrm{L}$ phenol concentration of real refinery wastewater. The new anode design of electrocoagulation cell permitted high efficiencies with lower energy consumption in comparison with other cell design used in previous studies.

Additionally, a study of Saeedi and Khalvati-Fahlyani [124] reported the treatment of gas refinery oily wastewater by electrocoagulation using aluminum electrodes. The effects of electrode distance, initial $\mathrm{pH}$, sodium sulfate $\left(\mathrm{Na}_{2} \mathrm{SO}_{4}\right)$ as a supporting electrolyte, polyaluminum chloride dosage as a coagulant aid, and current density on the efficiency of chemical oxygen demand (COD) removal were examined. The results revealed that the COD removal rate increases by applying more current density and polyaluminum chloride and, to a lesser extent, $\mathrm{Na}_{2} \mathrm{SO}_{4}$ dosage. The results also showed that $97 \%$ of COD can be removed at optimum operational conditions. Specific electrical energy consumption could be reduced from $19.48 \mathrm{kWh}(\mathrm{kg} \text { COD removal })^{-1}$ to $11.057 \mathrm{kWh}\left(\mathrm{kg} \mathrm{COD}\right.$ removal) ${ }^{-1}$ using $\mathrm{Na}_{2} \mathrm{SO}_{4}$ as a supporting electrolyte. Gas chromatographic analysis of raw and treated wastewater also revealed that most normal hydrocarbons (nearly 99\%) were removed during the electrocoagulation process.

Table 4 shows the advantages and disadvantages for the removal of petroleum compounds. 
Table 4. Advantages and disadvantages of commonly used methods for removal of petrochemical hydrocarbon pollutants.

\begin{tabular}{|c|c|c|c|}
\hline Method & UV Supported $^{1}$ & Advantages & Disadvantages \\
\hline Thermal incineration & No & Efficient destruction within short time & $\begin{array}{l}\text { High construction cost; potential formation of highly } \\
\text { toxic byproducts. }\end{array}$ \\
\hline $\begin{array}{l}\text { Chemical coagulation/flocculation } \\
\text { (with DAF/sedimentation/others) }\end{array}$ & No & $\begin{array}{l}\text { High removal efficiency; Usually easy to } \\
\text { operate }\end{array}$ & $\begin{array}{l}\text { High consumption of reactants; Production of hazardous } \\
\text { sludge; High operative costs for higher efficiencies } \\
\text { (reactants, air diffusers) }\end{array}$ \\
\hline $\begin{array}{c}\text { Electrochemical } \\
\text { coagulation/flotation }\end{array}$ & No & $\begin{array}{l}\text { High removal efficiency; Low reactant } \\
\text { consumption; Cheaper than chemical } \\
\text { coagulation }\end{array}$ & $\begin{array}{l}\text { Production of hazardous sludge (possibly larger than } \\
\text { with chemical coagulation [116]); High installation cost }\end{array}$ \\
\hline Fenton oxidation & Yes & Simplicity and efficiency & $\begin{array}{l}\text { Costly chemical addition; acidic conditions; secondary } \\
\text { pollutant formation. }\end{array}$ \\
\hline $\begin{array}{l}\text { Physical methods (DAF, } \\
\text { centrifugation) }\end{array}$ & No & $\begin{array}{l}\text { Low reactant consumption; No production of } \\
\text { byproducts }\end{array}$ & High energy requirements; Lower removal efficiency \\
\hline Coalescence on granular bed & No & $\begin{array}{c}\text { No reactant consumption; Cheap and easy to } \\
\text { operate }\end{array}$ & $\begin{array}{l}\text { Slow BTEX removal; May not be possible for all types of } \\
\text { wastewaters due to interference of other pollutants } \\
\text { (e.g., suspended solids); Lower removal efficiency }\end{array}$ \\
\hline Membrane separation & No & $\begin{array}{l}\text { High removal efficiency; Low/no reactant } \\
\text { consumption; No production of byproducts; } \\
\text { Possibility of recovery of the oily retentate; } \\
\text { Possibility of removing other pollutants } \\
\text { simultaneously }\end{array}$ & $\begin{array}{c}\text { High energy requirements; May require pretreatment } \\
\text { (another upstream secondary treatment) of wastewater; } \\
\text { High maintenance costs due to occurrence of } \\
\text { membrane fouling }\end{array}$ \\
\hline AOPs & Yes & $\begin{array}{l}\text { Possibility of total elimination of organic } \\
\text { pollution; Possibility of removing other } \\
\text { pollutants simultaneously }\end{array}$ & $\begin{array}{l}\text { Lower removal efficiency; Only adequate for } \\
\text { low-pollution wastewaters; High reactant consumption }\end{array}$ \\
\hline Biological treatment & No & $\begin{array}{l}\text { High removal efficiency; Low reactant } \\
\text { consumption; Cheap and easy to operate }\end{array}$ & $\begin{array}{c}\text { Production of sludge; Only adequate for biodegradable } \\
\text { wastewaters (may require pretreatment (another } \\
\text { upstream secondary treatment) }\end{array}$ \\
\hline
\end{tabular}


Table 4. Cont

\begin{tabular}{|c|c|c|c|}
\hline Method & UV Supported $^{1}$ & Advantages & Disadvantages \\
\hline Adsorption & No & $\begin{array}{l}\text { High removal efficiency; No reactant } \\
\text { consumption; Cheap (especially with low-cost } \\
\text { materials); Easy to operate; No production of } \\
\text { byproducts; Possibility of regeneration }\end{array}$ & $\begin{array}{l}\text { May not be adequate for finely dispersed emulsions; May } \\
\text { suffer interference of other pollutants }\end{array}$ \\
\hline Phytoremediation & No & Economics, aesthetic and ecologic advantages & $\begin{array}{l}\text { Time-consuming; incomplete metabolism and potential } \\
\text { increase in bioavailability of contaminants [125] }\end{array}$ \\
\hline Ozonation & Yes & Effective and fast removal of contaminants & $\begin{array}{l}\text { Low solubility of ozone in water; ozone scavengers } \\
\text { commonly found in environment; incomplete oxidation } \\
{[44]}\end{array}$ \\
\hline Plasma & No & $\begin{array}{l}\text { Can simultaneously remove gas pollutants, } \\
\text { airborne microbes, and even particles. }\end{array}$ & $\begin{array}{l}\text { May produce } \mathrm{O}_{3}, \mathrm{NO}_{\mathrm{x}} \text { and other harmful by-products. } \\
\text { High voltage and high energy consumption. }\end{array}$ \\
\hline Solvent extraction & No & Efficient method and very fast process & $\begin{array}{l}\text { High cost and environmentally unfit, heavy metals } \\
\text { cannot be removed by this process [126] }\end{array}$ \\
\hline Centrifugation & No & $\begin{array}{c}\text { Easy to process, no need for any solvent and } \\
\text { environmentally safe }\end{array}$ & $\begin{array}{l}\text { Large among of energy required, economically unfit and } \\
\text { lower size molecules difficult to settle down [127] }\end{array}$ \\
\hline Froth flotation & No & Easy to apply and less energy required & $\begin{array}{l}\text { Highly viscous oily wastewater cannot be offered to this } \\
\text { process [128] }\end{array}$ \\
\hline Ultrasonic irradiation & Yes & Fast and effective, no need any chemicals & Heavy equipment cost, unable to treat heavy metals [129] \\
\hline Surfactant EOR & Yes & $\begin{array}{l}\text { Easy to process and limited application in } \\
\text { heavy metals }\end{array}$ & $\begin{array}{l}\text { High cost, surfactant should be toxic, alternate process } \\
\text { required to remove surfactant and economically costly } \\
\text { [130] }\end{array}$ \\
\hline Freeze/thaw & No & $\begin{array}{l}\text { Short treatment process and suitable for } \\
\text { cold regions }\end{array}$ & Less effective and coastally process [131] \\
\hline Microwave irradiation & Yes & $\begin{array}{l}\text { Very fast and efficient and no need for } \\
\text { chemical addition }\end{array}$ & $\begin{array}{l}\text { Specially designed equipment, heavy costly and not } \\
\text { effective for large scale process [132] }\end{array}$ \\
\hline Electrokinetics & No & No need for chemical addition and fast process & Process is not easy and less effective [133] \\
\hline Pyrolysis & No & Large treatment capacity, fast and effective & High capital, maintenance and operating cost [134] \\
\hline
\end{tabular}


Table 4. Cont

\begin{tabular}{cccc}
\hline Method & UV Supported ${ }^{\mathbf{1}}$ & Advantages & Disadvantages \\
\hline $\begin{array}{c}\text { Stabilization/solidification } \\
\text { Oxidation }\end{array}$ & No & $\begin{array}{c}\text { Fast and efficient to produce PHC stabilized } \\
\text { compounds, low cost and capture the } \\
\text { heavy metals }\end{array}$ & $\begin{array}{c}\text { Loss of recyclable energy and less effective in } \\
\text { process [135] }\end{array}$ \\
\hline Land farming & Yes & $\begin{array}{c}\text { Rapid and complete removal of PHCs in } \\
\text { oilydge }\end{array}$ & $\begin{array}{c}\text { Large amount of chemical required, high cost and } \\
\text { environmentally unfit [136] }\end{array}$ \\
\hline Landfill & No & $\begin{array}{c}\text { Low cost and do not need much maintenance } \\
\text { and applicable to large quantity }\end{array}$ & Sand pollution and underground water pollution [137] \\
\hline Biopile/compositing & No & Less cost and large treatment capacity & Very slow process and required more place [138] \\
\hline Bioslurry & No & $\begin{array}{c}\text { Large treatment capacity, low cost, faster and } \\
\text { less area required for the process }\end{array}$ & Applicable in cold condition [139] \\
\hline & No & $\begin{array}{c}\text { Fastest degradation approach, great } \\
\text { PHC removal }\end{array}$ & High cost and applicable to small scale [140] \\
\hline
\end{tabular}




\section{Effect of Factors on Efficiency}

The efficiency of petroleum hydrocarbons removal was strongly affected by a series of factors (Table 5). In the following subsections, there is a brief overview of them.

Table 5. The effect of different factors on the efficiency of removal of BTEX compounds.

\begin{tabular}{|c|c|c|c|c|c|}
\hline Methods & $\mathrm{pH}$ & Time & $\begin{array}{l}\text { Temperature } \\
\quad\left({ }^{\circ} \mathbf{F}\right)\end{array}$ & BTEX Concentration & Ref. \\
\hline Thermal Incineration & - & $90 \mathrm{~min}$ & 700 & $\begin{array}{l}\text { Higher than } 20 \text { but less } \\
\text { than } 25 \% \text { of LEL }\end{array}$ & [141-143] \\
\hline Condensation & - & - & Ambient & $5000-10,000$ & [29] \\
\hline Biological degradation & 7 & $7-24 \mathrm{~d}$ & 50-105 & $>5000$ & {$[32,144]$} \\
\hline Absorption & $3-10$ & $>10 \mathrm{~s}$ & Normal & $500-15,000$ & [32] \\
\hline Adsorption & $6.5-9$ & $0.5-240 \mathrm{~min}$ & $<130$ & $\begin{array}{l}700-10,000 \text { (but always } \\
\text { less than } 25 \% \text { of LEL) }\end{array}$ & {$[33,145]$} \\
\hline Plasma catalysis & - & $120 \mathrm{~min}$ & 500 & 1000 & [45] \\
\hline Photocatalytic oxidation & - & 150-200 min & $450-500$ & $250-900$ & {$[46,47,146]$} \\
\hline Ozone-catalytic oxidation & - & $<45 \min$ & 300 & $\begin{array}{l}100-1000 \text { but always } \\
\text { less than } 25 \% \text { of LEL }\end{array}$ & [147] \\
\hline Membrane separation & $9.5-10.0$ & $60 \mathrm{~min}$ & Ambient & $\begin{array}{l}\text { Very low concentration } \\
\text { to } 25 \% \text { of LEL }\end{array}$ & {$[28,148]$} \\
\hline $\begin{array}{l}\text { Coagulation/flocculation } \\
\text { withsedimentation }\end{array}$ & $2.0-4.5$ & $36 \mathrm{~min}$ & Ambient & $\begin{array}{l}\text { coagulant: } 10-70 \\
\text { flocculent: } 1-3 \mathrm{ppm}\end{array}$ & [149] \\
\hline Flocculation with DAF & $7.7 \pm 0.4$ & 3-21 days & $\begin{array}{c}\text { room } \\
\text { temperature }\end{array}$ & $63.7-240 \mathrm{~g} / \mathrm{kg}$ & [150] \\
\hline Electrocoagulation & 9.5 & 3-20 h & 35 & $1500-2200 \mathrm{mg} / \mathrm{L}$ & {$[49,55]$} \\
\hline Centrifugation & - & 6 months & $40-150$ & 20-2000 mg/L & [56] \\
\hline Ozonation & $6.3,2.5,1.9$ & $0.45 \mathrm{~s}$ & Ambient & 50 mg/L & [151-153] \\
\hline
\end{tabular}

\subsection{Effect of Solution $p H$}

The $\mathrm{pH}$ of the solution is one of the most important factors affecting the chemical reactions that affect the structure of the pollutant, the surface properties of adsorbents and the pathway, and the reaction kinetics [154]. Veiga et al. (1999) studied the effect of $\mathrm{pH}$ on alkyl benzene degradation (between $\mathrm{pH} 3.5$ and 7.0) and found that alkylbenzene degradation increases with $\mathrm{pH}$ increase [155]. Lu et al. (2002) reported the maximum degradation for BTEX between $\mathrm{pH}$ values of 7.5 and 8.0 [156]. However, the ideal $\mathrm{pH}$ of the biofilter medium depends on the pollutant being treated and the characteristics of the microbial ecosystem [157].

A good reference is the application of the Fenton process for the purification of petroleum compounds. The success of this treatment depends on the generation of $\mathrm{OH}$. Higher concentrations of $\mathrm{H}_{2} \mathrm{O}_{2} / \mathrm{COD}$ in the presence of iron generated more hydroxyl radicals and enhanced process efficiency. However, excessive amounts of hydrogen peroxide and Fe particles had adverse effects on removal efficiency. The undesirable reactions between hydroxyl/hydroperoxyl radicals and excessive amounts of $\mathrm{H}_{2} \mathrm{O}_{2}$ and $\mathrm{Fe}$ ions may be explained by the following reactions.

$$
\begin{aligned}
& \mathrm{H}_{2} \mathrm{O}_{2}+\mathrm{HO}^{\bullet} \rightarrow \mathrm{H}_{2} \mathrm{O}+\mathrm{HO}_{2} \\
& \mathrm{Fe}^{2+}+\mathrm{HO}^{\bullet} \rightarrow \mathrm{Fe}^{3+}+\mathrm{OH}^{-} \\
& \mathrm{Fe}^{2+}+\mathrm{HO}_{2}^{\cdot} \rightarrow \mathrm{Fe}^{3+}+(\mathrm{OH})_{2}^{-} \\
& \mathrm{Fe}^{3+}+\mathrm{HO}_{2}^{\cdot} \rightarrow \mathrm{Fe}^{2+}+\mathrm{O}_{2}+\mathrm{H}^{+}
\end{aligned}
$$

Although higher concentrations of Fe ions might have been advantageous in terms of COD reduction by postcoagulation, a high dosage of iron ions scavenged the hydroxyl/hydroperoxyl radicals $[158,159] . \mathrm{pH}$ is also a determinant factor in the Fenton process. The highest concentration of $\mathrm{Fe}^{2+}$ occurred at $\mathrm{pH}$ values in the range of 2.0-4.0 and beyond which the efficiency decreased. Moreover, hydrogen peroxide is most stable at $\mathrm{pH}$ levels in the range of 3.0-4.0, and its decomposition at higher $\mathrm{pH}$ values formed another reason for the inefficiency of the process [158]. 


\subsection{Effect of Temperature}

Working temperature is an important factor affecting the decomposition of oil compounds. The microorganisms that most effectively degrade BTEX compounds in the biological processes are mesothermic, and their optimum activity temperatures are between 30 and $40{ }^{\circ} \mathrm{C}$. In fact, the proper temperature increases the rate of biofilm development and biomass accumulation [160]. Deeb and Alvarez-Cohen (1999) indicated that in the optimum range of operating temperature, the degradation performance on biofilter can increase 2 -fold by $10{ }^{\circ} \mathrm{C}$ increase in temperature [161]. This can be explained by the fact that an increase in temperature causes a decrease in BTEX compounds and dissolved oxygen in water and diffusion transfer increases. Due to the exothermic nature of the biodegradation reactions, the variation of temperature in the filter bed is a consequence of microbial activity [162].

\subsection{Effect of Reaction Time}

The reaction time is one of the most important variables affecting the design and operation of each chemical process. In fact, the reaction time is the time it takes to achieve the desired purification targets. In the catalytic ozonation processes, the adsorption, direct oxidation, and indirect oxidation processes are involved in removal, so the catalytic ozonation process will lead to higher yields than conventional ozonation over a shorter period of time [163].

\subsection{Effect of Ionic Strength}

The desorption rate of petroleum hydrocarbons decreased as the increase of ionic strength decreased, which may arise because the solubility of organic matter in nonpolar or weakly polar water usually decreases as the ionic strength increases. Lower solubility decreased the rate of petroleum hydrocarbon desorption in absorbent. Turner proposed that the increased ionic strength can compress the absorbent surface, similar to an electric double layer, thus changing the structure of organic matter and increasing the desorption of petroleum hydrocarbons. Therefore, the increased ionic strength also compresses the surface of clay and organic matter in absorbent on the surface of the electric double-layer structure, which decreases net negative charge in the absorbent, even when the absorbent is close to its isoelectric point. This is more conducive to the adsorption of hydrophobic organic compounds, resulting in the decreased desorption rate of petroleum hydrocarbons.

Special attention must be given to bilgewater [164]. Bilgewater is a complex shipboard wastewater composed of seawater, various fuels, lubrication oils, cooling water, and other pollutants (e.g., detergents, solvents, solid particulates) from various sources such as machinery washes, condensation, leaks, and other activities. The presence of oil-in-water emulsions makes bilgewater difficult to treat solely by gravity-driven separation processes and often requires the use of secondary treatment systems. The ionic strength of the aqueous phase is particularly important for electrostatically stabilized emulsions. When the ionic strength of a solution increases, the electrostatic shielding between droplets is reduced, which allows for increased droplet interaction. For example, Rios et al. [165] reported the influence of electrolytes on the destabilization of oil-in-water emulsions by breaking them using the inorganic salts calcium chloride and aluminum chloride. As expected, the addition of electrolytes lowered the zeta potential of the droplets, and destabilization of the emulsion was observed $[165,166]$. In addition, the presence of salts in an emulsion system can influence the solubility of nonionic surfactants [167] and increase the density of the aqueous phase, which can impact the stability of sterically stabilized emulsions. Given the impact of ionic strength on emulsion stabilization, electrical conductivities of bilgewater are often reported in bilgewater research. Electrical conductivity is a simple indirect method for measuring the ionic strength of a water sample. Conductivities of bilgewater have been reported to range from 0.679 to $8.4 \mathrm{mS} / \mathrm{cm}[168,169]$. 
It is important to mention that, usually, there is a noticeable difference from heavy oils to VOCs treatment. So, Table 6 shows the different types of hydrocarbons presented in petroleum wastewaters, and Table 7 shows the most common approach of them based on this classification.

Table 6. The physical properties for heavy hydrocarbons compared with lighter saturated and aromatic hydrocarbons.

\begin{tabular}{|c|c|c|c|c|c|c|c|}
\hline $\begin{array}{c}\text { Equivalent } \\
\text { Carbon Number } \\
\text { (EC) }\end{array}$ & $\begin{array}{c}\text { Water } \\
\text { Solubility } \\
(\mathrm{mg} / \mathrm{L})\end{array}$ & $\begin{array}{l}\text { Vapour } \\
\text { Pressure } \\
\text { (atm) }\end{array}$ & $\begin{array}{l}\log \left(K_{\text {oc }}\right) \\
\left(\mathrm{cm}^{3} / \mathrm{g}\right)\end{array}$ & $\underset{\left(\mathrm{cm}^{3} / \mathrm{cm}^{3}\right)}{\mathbf{H}}$ & $\begin{array}{l}\text { Retardation } \\
\text { Factor, Rf } \\
\quad \#\end{array}$ & \multicolumn{2}{|c|}{$\begin{array}{l}\text { Fugacity Level I } \\
\text { Partitioning (\%) }\end{array}$} \\
\hline \multirow[t]{2}{*}{$\begin{array}{c}\mathrm{EC}>12-16 \\
\text { aliphatic }\end{array}$} & $7.6 \times 10^{-4}$ & $4.8 \times 10^{-5}$ & 6.7 & 520 & $1.3 \times 10^{8}$ & Air & $1.8 \times 10^{-2}$ \\
\hline & & & & & & $\begin{array}{l}\text { Water } \\
\text { NAPL } \\
\text { Soil }\end{array}$ & $\begin{array}{c}1.9 \times 10^{-5} \\
70.0 \\
29.7\end{array}$ \\
\hline \multirow{2}{*}{$\begin{array}{c}\mathrm{EC}>12-16 \\
\text { aromatic }\end{array}$} & 5.8 & $4.8 \times 10^{-5}$ & 3.7 & $5.3 \times 10^{-2}$ & $1.3 \times 10^{5}$ & Air & $4.7 \times 10^{-4}$ \\
\hline & & & & & & $\begin{array}{l}\text { Water } \\
\text { NAPL } \\
\text { Soil }\end{array}$ & $\begin{array}{c}4.9 \times 10^{-2} \\
24.2 \\
75.8\end{array}$ \\
\hline \multirow{2}{*}{$\begin{array}{c}\text { EC > 16-35 } \\
\text { aliphatic }\end{array}$} & $2.5 \times 10^{-6}$ & $9.8 \times 10^{-7}$ & 8.8 & $4.9 \times 10^{3}$ & $1.6 \times 10^{10}$ & Air & $5.4 \times 10^{-4}$ \\
\hline & & & & & & $\begin{array}{c}\text { Water } \\
\text { NAPL } \\
\text { Soil }\end{array}$ & $\begin{array}{c}6.1 \times 10^{-8} \\
88.0 \\
12.0\end{array}$ \\
\hline \multirow[t]{2}{*}{$\begin{array}{l}\mathrm{EC}>16-21 \\
\text { aromatic }\end{array}$} & 0.65 & $1.1 \times 10^{-6}$ & 4.2 & $1.3 \times 10^{-2}$ & $4.0 \times 10^{5}$ & Air & $3.4 \times 10^{-4}$ \\
\hline & & & & & & $\begin{array}{c}\text { Water } \\
\text { NAPL } \\
\text { Soil }\end{array}$ & $\begin{array}{c}1.5 \times 10^{-2} \\
28.6 \\
71.4\end{array}$ \\
\hline \multirow[t]{2}{*}{$\begin{array}{c}\mathrm{EC}>21-35 \\
\text { aromatic }\end{array}$} & $6.6 \times 10^{-3}$ & $4.4 \times 10^{-10}$ & 5.1 & $6.7 \times 10^{-4}$ & $3.2 \times 10^{6}$ & Air & $1.9 \times 10^{-6}$ \\
\hline & & & & & & $\begin{array}{l}\text { Water } \\
\text { NAPL } \\
\text { Soil }\end{array}$ & $\begin{array}{c}1.6 \times 10^{-3} \\
38.9 \\
61.1\end{array}$ \\
\hline \multirow[t]{2}{*}{$\begin{array}{c}\text { EC > } 44 \text { heavy } \\
\text { hydrocarbon }\end{array}$} & $1.0 \times 10^{-4}$ & $4.1 \times 10^{-12}$ & 8.7 & $4.1 \times 10^{-8}$ & $1.3 \times 10^{10}$ & Air & $1.2 \times 10^{-14}$ \\
\hline & & & & & & $\begin{array}{c}\text { Water } \\
\text { NAPL } \\
\text { Soil }\end{array}$ & $\begin{array}{c}1.7 \times 10^{-7} \\
74.4 \\
25.6\end{array}$ \\
\hline Benzo [a] pyrene & $3.8 \times 10^{-3}$ & $2.1 \times 10^{-10}$ & 5.9 & $5.7 \times 10^{-4}$ & $2.0 \times 10^{7}$ & $\begin{array}{c}\text { Air } \\
\text { Water } \\
\text { NAPL } \\
\text { Soil }\end{array}$ & $\begin{array}{c}1.4 \times 10^{-7} \\
1.4 \times 10^{-4} \\
4.6 \\
95.4\end{array}$ \\
\hline
\end{tabular}

${ }^{1}$ The equivalent carbon (EC) number of a hydrocarbon is related to its boiling point (b.p.) normalized to the boiling point of an n-alkane series, or its retention time on a non-polar b.p. gas chromatographic (GC) column [170,171]. \# Aquifer properties: effective porosity 0.25 , $\mathrm{f}_{\mathrm{OC}} 0.025$ to 0.0025 , and bulk density $2500 / \mathrm{kg} / \mathrm{m}^{-3}$. Rf $=1+\left(\mathrm{K}_{\mathrm{d}} \times\right.$ bulk density)/porosity. $\mathrm{K}_{\mathrm{oc}}$ is the soil organic carbon-water partitioning coefficient. H is Henry's Law Constant.

Different types of oil and petrochemical industry wastewater with different components were studied. The methods described above are mostly used for petrochemical wastewater treatment but are generally described in Table 7 as anaerobic and hybrid methods for the treatment of most heavy oil and petrochemical wastewater. 
Moreover, in the adsorption process, in the early stages, a large number of free-surface adsorbents are available for adsorption, and after a while, the remaining surface spaces are not readily available, being occupied by the absorbing material, due to the repulsive forces between the soluble molecules and the solid-phase mass. In the advanced oxidation process, xylene is eliminated more than ethylbenzene, toluene, and benzene, and the amount of xylene and ethylbenzene adsorption is very close, and adsorption is much higher than benzene and toluene. This condition is due to lower benzene and toluene dissolution than ethylbenzene and xylene and higher molecular weight and higher boiling point of xylene and ethylbenzene than benzene $[145,172,173]$. $\mathrm{Lu}$ and coworkers found that in a preliminary concentration of $20060 \mathrm{mg} / \mathrm{L}$ of benzene and toluene, the amount of toluene adsorbed per unit mass of mass was absorbed more than benzene [174]. Aivalioti et al. reported that the adsorption capacity of diatoms for toluene removal is greater than that of benzene [174]. In their studies, Daifullah and Grizzis reported that the amount of toluene adsorption per unit mass was greater than that of benzene [175]. Su et al. showed that the adsorption capacity of benzene and toluene by nanotubes modified with sodium hypochlorite at an initial concentration of $200 \mathrm{mg} / \mathrm{L}$, a contact time of $240 \mathrm{~min}$, and a concentration of adsorbent $600 \mathrm{mg} / \mathrm{L}$ was 212 and $225 \mathrm{mg} / \mathrm{g}$ of absorbent. The toluene adsorption capacity was more than benzene [176]. In a study by Garoma on removing oil compounds using the conventional ozonation process, the removal efficiency of these compounds was reported to be $27 \%$ [3]. 
Table 7. Anaerobic and hybrid (anaerobic-aerobic) bioreactors used for hydrocarbon-containing wastewater treatment [177].

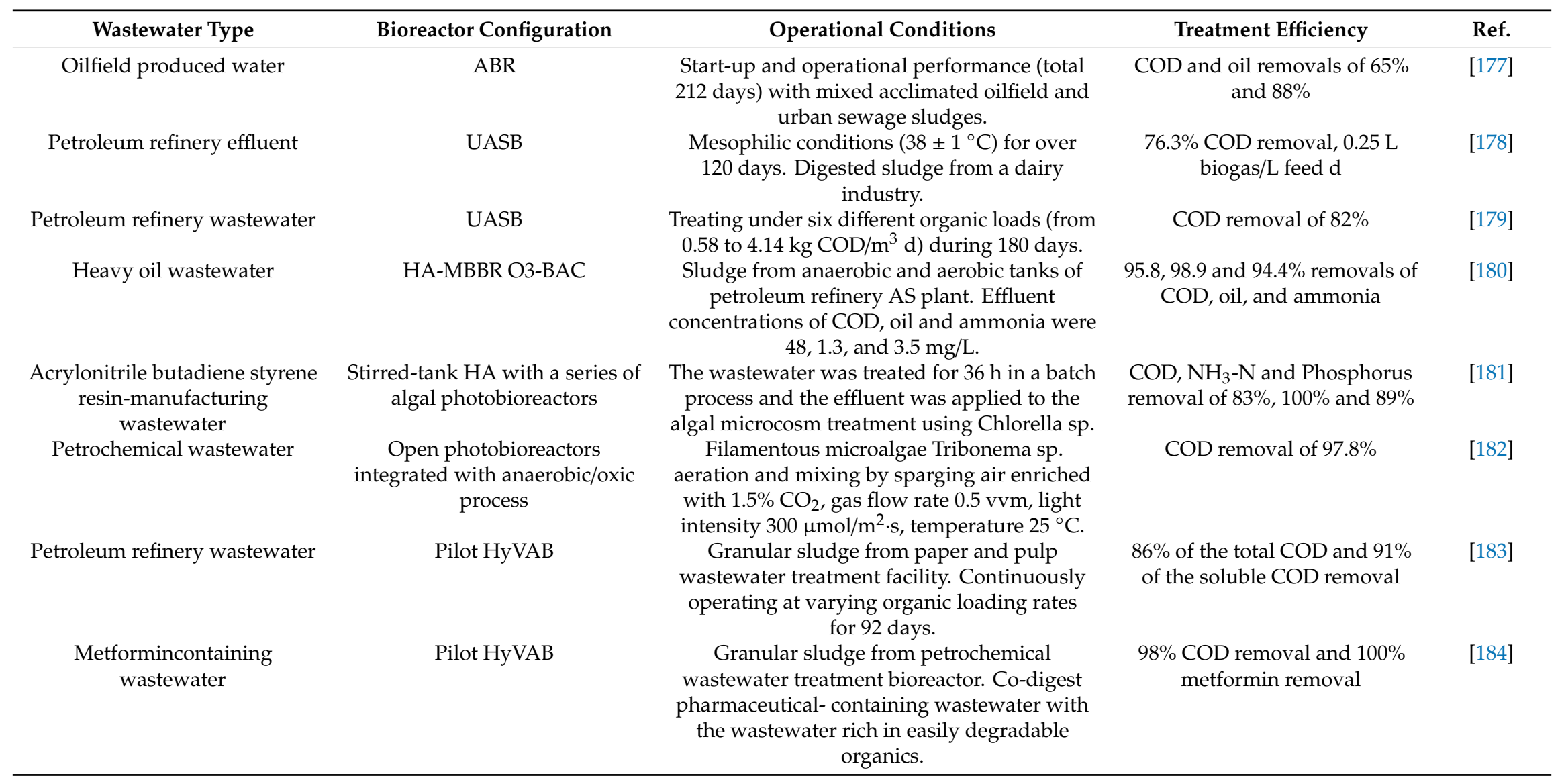




\section{Conclusions}

Oil compounds are one of the most hazardous pollutants in water and wastewater treatment. The main source of emissions in the environment is petrochemical, transportation, and industrial activities. So, the petrochemical hydrocarbons must be treated. This review focused on major techniques applied to petrochemical wastewater treatment. The major conclusions can be given as

- Conventional refining techniques are not able to affect the effective elimination of oil compounds, and the high concentrations of these pollutants may affect the activity and efficiency of the treatment plant due to the high toxicity of these compounds that affects the activity of the active sludge pool and creates layers in the film which can cause blockage of the tubes.

- Purification and removal of oil pollutants are necessary, especially in industries; the output of sewage chemical purification (coagulation, DAF flocculation) can be transmitted to the biologic reactor for further purification.

- Electromethods are more advanced than conventional physical and chemical methods, such as electrocoagulation and flotation.

- Physical methods can separate large amounts of petroleum compounds, and, in some cases, these compounds can be recycled with a number of processes.

- Third-party refinement can provide water reuse targets with methods such as nanofiltration, reverse osmosis, and advanced oxidation.

- Adsorption is an emergency technology for petrochemical wastewater treatment that can be applied by using minerals and organic materials. By using low-cost adsorbent materials and combining the adsorption process with one of the advanced methods, sludge production may be lowered and can reduce the cost of the process.

Author Contributions: Writing-Original draft, L.M., A.R., E.B., H.D., M.A.B.H.S. and G.Z.K.; Writing-review \& editing, L.M., A.R., E.B., H.D., M.A.B.H.S. and G.Z.K.; Supervision, L.M., A.R., G.Z.K. All authors have read and agreed to the published version of the manuscript.

Funding: This research received no external funding.

Conflicts of Interest: The authors declare no conflict of interest.

\section{References}

1. Daraei, H.; Mittal, A.; Noorisepehr, M.; Daraei, F. Kinetic and equilibrium studies of adsorptive removal of phenol onto eggshell waste. Environ. Sci. Pollut. Res. 2013, 20, 4603-4611. [CrossRef] [PubMed]

2. Durmusoglu, E.; Taspinar, F.; Karademir, A. Health risk assessment of BTEX emissions in the landfill environment. J. Hazard. Mater. 2010, 176, 870-877. [CrossRef] [PubMed]

3. Tian, X.; Song, Y.; Shen, Z.; Zhou, Y.; Wang, K.; Jin, X.; Han, Z.; Liu, T. A comprehensive review on toxic petrochemical wastewater pretreatment and advanced treatment. J. Clean. Prod. 2020, 245, 118692. [CrossRef]

4. Garoma, T.; Gurol, M.D.; Osibodu, O.; Thotakura, L. Treatment of groundwater contaminated with gasoline components by an ozone/UV process. Chemosphere 2008, 73, 825-831. [CrossRef] [PubMed]

5. Skodras, A.; Christopoulos, C.; Ebrahimi, T. The JPEG 2000 still image compression standard. IEEE Signal Process. Mag. 2001, 18, 36-58. [CrossRef]

6. Singh, J.G.; Chang-Yen, I.; Stoute, V.A.; Chatergoon, L. Hydrocarbon levels in edible fish, crabs and mussels from the marine environment of Trinidad. Mar. Pollut. Bull. 1992, 24, 270-272. [CrossRef]

7. Shim, H.; Shin, E.; Yang, S.-T. A continuous fibrous-bed bioreactor for BTEX biodegradation by a co-culture of Pseudomonas putida and Pseudomonas fluorescens. Adv. Environ. Res. 2002, 7, 203-216. [CrossRef]

8. Cerniglia, C.E.; Sutherland, J.B. Relative roles of bacteria and fungi in polycyclic aromatic hydrocarbon biodegradation and bioremediation of contaminated soils. In Fungi in Biogeochemical Cycles; Gadd, G.M., Ed.; Cambridge University Press: Cambridge, UK, 2006; pp. 182-211.

9. Schneider, P.; Lorinci, G.; Gebefugi, I.L.; Heinrich, J.; Kettrup, A.; Wichmann, H.E. Vertical and horizontal variability of volatile organic compounds in homes in Eastern Germany. J. Expo. Sci. Environ. Epidemiol. 1999, 9, 282-292. [CrossRef] 
10. Sairat, T.; Homwuttiwong, S.; Homwutthiwong, K.; Ongwandee, M. Investigation of gasoline distributions within petrol stations: Spatial and seasonal concentrations, sources, mitigation measures, and occupationally exposed symptoms. Environ. Sci. Pollut. Res. 2015, 22, 13870-13880. [CrossRef]

11. El-Din, N.M.; Abdel-Moati, M.A.R. Accumulation of Trace Metals, Petroleum Hydrocarbons, and Polycyclic Aromatic Hydrocarbons in Marine Copepods from the Arabian Gulf. Bull. Environ. Contam. Toxicol. 2001, 66, 110-117. [CrossRef]

12. Veellu, R. Petroleum hydrocarbon along the coastal areas of Port Dickson. Petranika 1989, 12, 349-355.

13. Quinlan, M. The Implications of Labour Market Restructuring in Industrialized Societies for Occupational Health and Safety. Econ. Ind. Democr. 1999, 20, 427-460. [CrossRef]

14. Shaughnessy, P.D. Population Assessment of New Zealand Fur Seals and Australian Sea Lions in Some South Australian Breeding Colonies and Haul-Out Sites 2003-2004. Rep. Dep. Environ. Herit. 2004, 13, 87-98.

15. Gkorezis, P.; Daghio, M.; Franzetti, A.; Van Hamme, J.D.; Sillen, W.; Vangronsveld, J. The Interaction between Plants and Bacteria in the Remediation of Petroleum Hydrocarbons: An Environmental Perspective. Front. Microbiol. 2016, 7, 1836. [CrossRef] [PubMed]

16. Xie, H.; Du, Q.; Li, H.; Zhou, G.; Chen, S.; Jiao, Z.; Ren, J. Catalytic combustion of volatile aromatic compounds over CuO-CeO2 catalyst. Korean J. Chem. Eng. 2017, 34, 1944-1951. [CrossRef]

17. Bray, J.R.; Curtis, J.T. An Ordination of the Upland Forest Communities of Southern Wisconsin. Ecol. Monogr. 1957, 27, 325-349. [CrossRef]

18. El Samra, M.I.; Emara, H.I.; Shunbo, F. Dissolved petroleum hydrocarbon in the northwestern Arabian Gulf. Mar. Pollut. Bull. 1986, 17, 65-68. [CrossRef]

19. Payne, J.R.; McNabb, G.D., Jr.; Clayton, J.R., Jr. Oil-weathering behavior in Arctic environments. Polar Res. 1991, 10, 631-662. [CrossRef]

20. Ji, H.; Gong, Y.; Duan, J.; Zhao, D.; Liu, W. Degradation of petroleum hydrocarbons in seawater by simulated surface-level atmospheric ozone: Reaction kinetics and effect of oil dispersant. Mar. Pollut. Bull. 2018, 135, 427-440. [CrossRef]

21. Mango, F.D. The light hydrocarbons in petroleum: A critical review. Org. Geochem. 1997, 26, 417-440. [CrossRef]

22. Najafi, A.R.; Rahimpour, M.R.; Jahanmiri, A.H.; Roostaazad, R.; Arabian, D.; Ghobadi, Z. Enhancing biosurfactant production from an indigenous strain of Bacillus mycoides by optimizing the growth conditions using a response surface methodology. Chem. Eng. J. 2010, 163, 188-194. [CrossRef]

23. Jones, K.C.; de Voogt, P. Persistent organic pollutants (POPs): State of the science. Environ. Pollut. 1999, 100, 209-221. [CrossRef]

24. Silliman, B.R.; van de Koppel, J.; McCoy, M.W.; Diller, J.; Kasozi, G.N.; Earl, K.; Adams, P.N.; Zimmerman, A.R. Degradation and resilience in Louisiana salt marshes after the BP-Deepwater Horizon oil spill. Proc. Natl. Acad. Sci. USA 2012, 109, 11234. [CrossRef] [PubMed]

25. Ahmed, F.; Anm, F.; Ahmed, F.; Anm, F. A Review on Environmental Contamination of Petroleum Hydrocarbons and its Biodegradation. Int. J. Environ. Sci. Nat. Resour. 2018, 11, 63-69.

26. Logeshwaran, P.; Megharaj, M.; Chadalavada, S.; Bowman, M.; Naidu, R. Petroleum hydrocarbons (PH) in groundwater aquifers: An overview of environmental fate, toxicity, microbial degradation and risk-based remediation approaches. Environ. Technol. Innov. 2018, 10, 175-193. [CrossRef]

27. Li, Y.; Zhao, Y.; Peng, S.; Zhou, Q.; Ma, L.Q. Temporal and spatial trends of total petroleum hydrocarbons in the seawater of Bohai Bay, China from 1996 to 2005. Mar. Pollut. Bull. 2010, 60, 238-243. [CrossRef]

28. Huang, B.; Lei, C.; Wei, C.; Zeng, G. Chlorinated volatile organic compounds (Cl-VOCs) in environment-Sources, potential human health impacts, and current remediation technologies. Environ. Int. 2014, 71, 118-138. [CrossRef]

29. Luengas, A.; Barona, A.; Hort, C.; Gallastegui, G.; Platel, V.; Elias, A. A review of indoor air treatment technologies. Rev. Environ. Sci. Bio/Technol. 2015, 14, 499-522. [CrossRef]

30. Tsai, T.-T.; Sah, J.; Kao, C.-M. Application of iron electrode corrosion enhanced electrokinetic-Fenton oxidation to remediate diesel contaminated soils: A laboratory feasibility study. J. Hydrol. 2010, 380, 4-13. [CrossRef]

31. Vilve, M.; Vilhunen, S.; Vepsäläinen, M.; Kurniawan, T.A.; Lehtonen, N.; Isomäki, H.; Sillanpää, M. Degradation of 1,2-dichloroethane from wash water of ion-exchange resin using Fenton's oxidation. Environ. Sci. Pollut. Res. 2010, 17, 875-884. [CrossRef] 
32. Lu, Y.; Liu, J.; Lu, B.; Jiang, A.; Wan, C. Study on the removal of indoor VOCs using biotechnology. J. Hazard. Mater. 2010, 182, 204-209. [CrossRef]

33. Jo, W.-K.; Yang, C.-H. Granular-activated carbon adsorption followed by annular-type photocatalytic system for control of indoor aromatic compounds. Sep. Purif. Technol. 2009, 66, 438-442. [CrossRef]

34. Campo, R.; Di Bella, G. Petrochemical slop wastewater treatment by means of aerobic granular sludge: Effect of granulation process on bio-adsorption and hydrocarbons removal. Chem. Eng. J. 2019, 378. [CrossRef]

35. de Abreu Domingos, R.; da Fonseca, F.V. Evaluation of adsorbent and ion exchange resins for removal of organic matter from petroleum refinery wastewaters aiming to increase water reuse. J. Environ. Manag. 2018, 214, 362-369. [CrossRef] [PubMed]

36. Esmaeili, A.; Saremnia, B. Comparison study of adsorption and nanofiltration methods for removal of total petroleum hydrocarbons from oil-field wastewater. J. Pet. Sci. Eng. 2018, 171, 403-413. [CrossRef]

37. Filatova, E.G.; Soboleva, V.G. Extraction of oil and petroleum products from water solutions by natural adsorbents. Izv. Vyss. Uchebnykh Zaved. Seriya Khimiya Khimicheskaya Tekhnologiya 2019, 62, 131-137. [CrossRef]

38. Mohammadi, M.; Sedighi, M.; Hemati, M. Removal of petroleum asphaltenes by improved activity of NiO nanoparticles supported on green AlPO-5 zeolite: Process optimization and adsorption isotherm. Petroleum 2019. [CrossRef]

39. Nazifa, T.H.; Hadibarata, T.; Yuniarto, A.; Elshikh, M.S.; Syafiuddin, A. Equilibrium, Kinetic and Thermodynamic Analysis Petroleum Oil Adsorption from Aqueous Solution by Magnetic Activated Carbon. In IOP Conference Series: Materials Science and Engineering; IOP Publishing: Bristol, UK, 2019.

40. Sadare, O.O.; Masitha, M.; Yoro, K.O.; Daramola, M.O. Removal of sulfur (e.g., DBT) from petroleum distillates using activated carbon in a continuous packed-bed adsorption column. In Proceedings of the World Congress on Engineering and Computer Science, WCECS 2018, San Francisco, CA, USA, 23-25 October 2018; pp. 509-513.

41. Salehi, E.; Shafie, M. Adsorptive removal of acetaldehyde from water using strong anionic resins pretreated with bisulfite: An efficient method for spent process water recycling in petrochemical industry. J. Water Process Eng. 2020, 33. [CrossRef]

42. Shahat, A.; Hassan, H.M.A.; El-Shahat, M.F.; El Shahawy, O.; Awual, M.R. Visual nickel(II) ions treatment in petroleum samples using a mesoporous composite adsorbent. Chem. Eng. J. 2018, 334, 957-967. [CrossRef]

43. Yurmazova, T.A.; Shakhova, N.B.; Tuan, H.T.; Plankina, M.V. Adsorption of petroleum substances and inorganic ions from aqueous solutions using mineral sorbent. Bull. Tomsk Polytech. Univ. Geo Assets Eng. 2018, 329, 125-134.

44. Alcántara-Garduño, M.E.; Okuda, T.; Nishijima, W.; Okada, M. Ozonation of trichloroethylene in acetic acid solution with soluble and solid humic acid. J. Hazard. Mater. 2008, 160, 662-667. [CrossRef] [PubMed]

45. Hoeben, W.F.L.M.; Beckers, F.J.C.M.; Pemen, A.J.M.; van Heesch, E.J.M.; Kling, W.L. Oxidative degradation of toluene and limonene in air by pulsed corona technology. J. Phys. D Appl. Phys. 2012, 45, 055202. [CrossRef]

46. Shiraishi, F.; Ishimatsu, T. Toluene removal from indoor air using a miniaturized photocatalytic air purifier including a preceding adsorption/desorption unit. Chem. Eng. Sci. 2009, 64, 2466-2472. [CrossRef]

47. Yokosuka, Y.; Oki, K.; Nishikiori, H.; Tatsumi, Y.; Tanaka, N.; Fujii, T. Photocatalytic degradation of trichloroethylene using $\mathrm{N}$-doped $\mathrm{TiO} 2$ prepared by a simple sol-gel process. Res. Chem. Intermed. 2009, 35, 43-53. [CrossRef]

48. Hubbard, H.; Coleman, B.; Sarwar, G.; Corsi, R. Abstract. Indoor Air 2005, 15, 432-444. [CrossRef]

49. Dąbrowski, A.; Podkościelny, P.; Hubicki, Z.; Barczak, M. Adsorption of phenolic compounds by activated carbon-A critical review. Chemosphere 2005, 58, 1049-1070. [CrossRef]

50. Derwent, R.G.; Jenkin, M.E.; Saunders, S.M.; Pilling, M.J. Photochemical ozone creation potentials for organic compounds in northwest Europe calculated with a master chemical mechanism. Atmos. Environ. 1998, 32, 2429-2441. [CrossRef]

51. Chan, K.Y.; Van Zwieten, L.; Meszaros, I.; Downie, A.; Joseph, S. Agronomic values of greenwaste biochar as a soil amendment. Soil Res. 2008, 45, 629-634. [CrossRef]

52. Feron, V.J.; Til, H.P.; de Vrijer, F.; van Bladeren, P.J. Toxicology of Volatile Organic Compounds in Indoor Air and Strategy for Further Research. Indoor Environ. 1992, 1, 69-81.

53. Nemecek-Marshall, M.; Wojciechowski, C.; Kuzma, J.; Silver, G.M.; Fall, R. Marine Vibrio species produce the volatile organic compound acetone. Appl. Environ. Microbiol. 1995, 61, 44-47. [CrossRef] 
54. Mitsui, T.; Tsutsui, K.; Matsui, T.; Kikuchi, R.; Eguchi, K. Catalytic abatement of acetaldehyde over oxide-supported precious metal catalysts. Appl. Catal. B Environ. 2008, 78, 158-165. [CrossRef]

55. Patnaik, P. A Comprehensive Guide to the Hazardous Properties of Chemical Substances; John Wiley \& Sons: Hoboken, NJ, USA, 2007.

56. Gaunt, J.L.; Lehmann, J. Energy Balance and Emissions Associated with Biochar Sequestration and Pyrolysis Bioenergy Production. Environ. Sci. Technol. 2008, 42, 4152-4158. [CrossRef]

57. Agnihotri, S.; Zheng, Y.; Mota, J.P.B.; Ivanov, I.; Kim, P. Practical Modeling of Heterogeneous Bundles of Single-Walled Carbon Nanotubes for Adsorption Applications: Estimating the Fraction of Open-Ended Nanotubes in Samples. J. Phys. Chem. C 2007, 111, 13747-13755. [CrossRef]

58. Ding, Z.; Wan, Y.; Hu, X.; Wang, S.; Zimmerman, A.R.; Gao, B. Sorption of lead and methylene blue onto hickory biochars from different pyrolysis temperatures: Importance of physicochemical properties. J. Ind. Eng. Chem. 2016, 37, 261-267. [CrossRef]

59. Lehmann, J. A handful of carbon. Nature 2007, 447, 143-144. [CrossRef]

60. Li, L.; Liu, S.; Liu, J. Surface modification of coconut shell based activated carbon for the improvement of hydrophobic VOC removal. J. Hazard. Mater. 2011, 192, 683-690. [CrossRef]

61. Sun, K.; Keiluweit, M.; Kleber, M.; Pan, Z.; Xing, B. Sorption of fluorinated herbicides to plant biomass-derived biochars as a function of molecular structure. Bioresour. Technol. 2011, 102, 9897-9903. [CrossRef]

62. Tang, D.; Zheng, Z.; Lin, K.; Luan, J.; Zhang, J. Adsorption of p-nitrophenol from aqueous solutions onto activated carbon fiber. J. Hazard. Mater. 2007, 143, 49-56. [CrossRef]

63. Xie, T.; Reddy, K.R.; Wang, C.; Yargicoglu, E.; Spokas, K. Characteristics and Applications of Biochar for Environmental Remediation: A Review. Crit. Rev. Environ. Sci. Technol. 2015, 45, 939-969. [CrossRef]

64. Nicodem, D.E.; Guedes, C.L.B.; Correa, R.J.; Fernandes, M.C.Z. Photochemical processes and the environmental impact of petroleum spills. Biogeochemistry 1997, 39, 121-138. [CrossRef]

65. Snape, I.; Harvey, P.M.; Ferguson, S.H.; Rayner, J.L.; Revill, A.T. Investigation of evaporation and biodegradation of fuel spills in Antarctica I. A chemical approach using GC-FID. Chemosphere 2005, 61, 1485-1494. [CrossRef] [PubMed]

66. Borhan, A.; Yusup, S.; Lim, J.W.; Show, P.L. Characterization and modelling studies of activated carbon produced from rubber-seed shell using $\mathrm{KOH}$ for $\mathrm{CO} 2$ adsorption. Processes 2019, 7, 855. [CrossRef]

67. Ge, M.; Xi, Z.; Zhu, C.; Liang, G.; Yang, Y.; Hu, G.; Jamal, L.; Alam, S.M.J. Adsorption process and properties analyses of a pure magadiite and a modified magadiite on rhodamine-B from an aqueous solution. Processes 2019, 7, 565. [CrossRef]

68. Jung, K.; Oh, S.; Bak, H.; Song, G.H.; Kim, H.T. Adsorption of arsenic and lead onto stone powder and chitosan-coated stone powder. Processes 2019, 7, 599. [CrossRef]

69. Nicolaou, E.; Philippou, K.; Anastopoulos, I.; Pashalidis, I. Copper adsorption by magnetized pine-needle biochar. Processes 2019, 7,903. [CrossRef]

70. Shukrullah, S.; Naz, M.Y.; Mohamed, N.M.; Ibrahim, K.A.; AbdEl-Salam, N.M.; Ghaffar, A. CVD synthesis, functionalization and CO2 adsorption attributes of multiwalled carbon nanotubes. Processes 2019, 7, 634. [CrossRef]

71. Ucán, C.A.; Abatal, M.; Romero, C.M.; Franseschi, F.A.; Elias, M.A.R.; Lozano, D.C. Removal of an ethoxylated alkylphenol by adsorption on zeolites and photocatalysis with TiO2/Ag. Processes 2019, 7, 889. [CrossRef]

72. Yu, D.; Morisada, S.; Kawakita, H.; Ohto, K.; Inoue, K.; Song, X.; Zhang, G. Selective cesium adsorptive removal on using crosslinked tea leaves. Processes 2019, 7, 412. [CrossRef]

73. Zhang, J.; Deng, R.; Ren, B.; Yaseen, M.; Hursthouse, A. Enhancing the removal of Sb (III) from water: A Fe3O4@HCO composite adsorbent caged in sodium alginate microbeads. Processes 2020, 8, 44. [CrossRef]

74. Anastopoulos, I.; Karamesouti, M.; Mitropoulos, A.C.; Kyzas, G.Z. A review for coffee adsorbents. J. Mol. Liq. 2017, 229, 555-565. [CrossRef]

75. Kyzas, G.Z.; Deliyanni, E.A.; Bikiaris, D.N.; Mitropoulos, A.C. Graphene composites as dye adsorbents: Review. Chem. Eng. Res. Des. 2018, 129, 75-88. [CrossRef]

76. Deliyanni, E.A.; Kyzas, G.Z.; Triantafyllidis, K.S.; Matis, K.A. Activated carbons for the removal of heavy metal ions: A systematic review of recent literature focused on lead and arsenic ions. Open Chem. 2015, 13, 699-708. [CrossRef] 
77. DesMarais, T.A.; Stone, K.J.; Dyer, J.C.; Hird, B.; Goldman, S.A.; Seiden, P. Absorbent Foam Materials for Aqueous Fluids Made from High Internal Phase Emulsions Having Very High Water-to-oil Ratios. U.S. Patent 5,650,222, 1997.

78. Choi, H.M.; Cloud, R.M. Natural sorbents in oil spill cleanup. Environ. Sci. Technol. 1992, 26, 772-776. [CrossRef]

79. Schrader, E. A practical composition of organic, synthetic and inorganic sorbents. Clean Gulf. 1993, 93, 17-22.

80. Choi, H.-M.; Kwon, H.-J.; Moreau, J.P. Cotton Nonwovens as Oil Spill Cleanup Sorbents. Text. Res. J. 1993, 63, 211-218. [CrossRef]

81. Andreozzi, R.; Caprio, V.; Insola, A.; Marotta, R.; Sanchirico, R. Advanced oxidation processes for the treatment of mineral oil-contaminated wastewaters. Water Res. 2000, 34, 620-628. [CrossRef]

82. Boudouch, O.; Daoud, E.; Mariem, K.; Benadda, B. Influence of Soil Air Permeability Change on Soil Vapour Extraction Systems Design. CLEAN-Soil Air Water 2012, 40, 461-471. [CrossRef]

83. Farhan, S.; Holsen, T.M.; Budiman, J. Interaction of Soil Air Permeability and Soil Vapor Extraction. J. Environ. Eng. 2001, 127, 32-37. [CrossRef]

84. García-Herruzo, F.; Gómez-Lahoz, C.; Rodríguez-Jiménez, J.J.; Wilson, D.J.; García-Delgado, R.A.; Rodríguez-Maroto, J.M. Influence of water evaporation on soil vapor extraction (SVE). Water Sci. Technol. 1994, 30, 115-118. [CrossRef]

85. Huon, G.; Simpson, T.; Holzer, F.; Maini, G.; Will, F.; Kopinke, F.-D.; Roland, U. In Situ Radio-Frequency Heating for Soil Remediation at a Former Service Station: Case Study and General Aspects. Chem. Eng. Technol. 2012, 35, 1534-1544. [CrossRef]

86. Preis, S.; Klauson, D.; Gregor, A. Potential of electric discharge plasma methods in abatement of volatile organic compounds originating from the food industry. J. Environ. Manag. 2013, 114, 125-138. [CrossRef] [PubMed]

87. Revah, S.; Morgan-Sagastume, J.M. Methods of Odor and VOC Control. In Biotechnology for Odor and Air Pollution Control; Shareefdeen, Z., Singh, A., Eds.; Springer: Berlin/Heidelberg, Germany, 2005; pp. $29-63$.

88. Hackam, R.; Aklyama, H. Air pollution control by electrical discharges. IEEE Trans. Dielectr. Electr. Insul. 2000, 7, 654-683. [CrossRef]

89. Urashima, K.; Jen-Shih, C. Removal of volatile organic compounds from air streams and industrial flue gases by non-thermal plasma technology. IEEE Trans. Dielectr. Electr. Insul. 2000, 7, 602-614. [CrossRef]

90. Satoh, K.; Matsuzawa, T.; Itoh, H. Decomposition of benzene in a corona discharge at atmospheric pressure. Thin Solid Films 2008, 516, 4423-4429. [CrossRef]

91. Schmid, S.; Jecklin, M.C.; Zenobi, R. Degradation of volatile organic compounds in a non-thermal plasma air purifier. Chemosphere 2010, 79, 124-130. [CrossRef]

92. Karn, B.; Kuiken, T.; Otto, M. Nanotechnology and in situ remediation: A review of the benefits and potential risks. Environ. Health Perspect. 2009, 117, 1813-1831. [CrossRef]

93. Singh, P.; Ojha, A.; Borthakur, A.; Singh, R.; Lahiry, D.; Tiwary, D.; Mishra, P.K. Emerging trends in photodegradation of petrochemical wastes: A review. Environ. Sci. Pollut. Res. 2016, 23, 22340-22364. [CrossRef]

94. Lee, J.Y.; Choi, J.-H. Sonochemical Synthesis of Ce-doped TiO2 Nanostructure: A Visible-Light-Driven Photocatalyst for Degradation of Toluene and O-Xylene. Materials 2019, 12, 1265. [CrossRef]

95. Laokiat, L.; Khemthong, P.; Grisdanurak, N.; Sreearunothai, P.; Pattanasiriwisawa, W.; Klysubun, W. Photocatalytic degradation of benzene, toluene, ethylbenzene, and xylene (BTEX) using transition metal-doped titanium dioxide immobilized on fiberglass cloth. Korean J. Chem. Eng. 2011, 29, 377-383. [CrossRef]

96. Mahanty, B.; Jesudas, S.; Padmaprabha, A. Toxicity of surface functionalized iron oxide nanoparticles toward pure suspension culture and soil microcosm. Environ. Nanotechnol. Monit. Manag. 2019, 12, 100235. [CrossRef]

97. Tchobanoglous, G.; Burton, F.L.; Stensel, H.D. Wastewater Engineering Treatment and Reuse; McGraw-Hill Higher Education: Boston, MA, USA, 2003.

98. Lim, H.-N.; Choi, H.; Hwang, T.-M.; Kang, J.-W. Characterization of ozone decomposition in a soil slurry: Kinetics and mechanism. Water Res. 2002, 36, 219-229. [CrossRef] 
99. Chen, T.; Delgado, A.G.; Yavuz, B.M.; Maldonado, J.; Zuo, Y.; Kamath, R.; Westerhoff, P.; Krajmalnik-Brown, R.; Rittmann, B.E. Interpreting Interactions between Ozone and Residual Petroleum Hydrocarbons in Soil. Environ. Sci. Technol. 2017, 51, 506-513. [CrossRef] [PubMed]

100. Zazo, J.A.; Casas, J.A.; Mohedano, A.F.; Gilarranz, M.A.; Rodríguez, J.J. Chemical Pathway and Kinetics of Phenol Oxidation by Fenton's Reagent. Environ. Sci. Technol. 2005, 39, 9295-9302. [CrossRef] [PubMed]

101. Nelson, M.D.; Parker, B.L.; Al, T.A.; Cherry, J.A.; Loomer, D. Geochemical Reactions Resulting from In Situ Oxidation of PCE-DNAPL by KMnO4 in a Sandy Aquifer. Environ. Sci. Technol. 2001, 35, 1266-1275. [CrossRef]

102. Bajagain, R.; Gautam, P.; Jeong, S.-W. Degradation of petroleum hydrocarbons in unsaturated soil and effects on subsequent biodegradation by potassium permanganate. Environ. Geochem. Health 2019. [CrossRef]

103. Arslan, İ.; Balcioǧlu, I.A.; Bahnemann, D.W. Advanced chemical oxidation of reactive dyes in simulated dyehouse effluents by ferrioxalate-Fenton/UV-A and TiO2/UV-A processes. Dyes Pigment. 2000, 47, 207-218. [CrossRef]

104. Mohammadi, L.; Bazrafshan, E.; Noroozifar, M.; Ansari-Moghaddam, A.; Barahuie, F.; Balarak, D. Adsorptive removal of Benzene and Toluene from aqueous environments by cupric oxide nanoparticles: Kinetics and isotherm studies. J. Chem. 2017, 2017. [CrossRef]

105. Mohammadi, L.; Bazrafshan, E.; Noroozifar, M.; Ansari-Moghaddam, A.; Barahuie, F.; Balarak, D. Removing 2,4-dichlorophenol from aqueous environments by heterogeneous catalytic ozonation using synthesized $\mathrm{MgO}$ nanoparticles. Water Sci. Technol. 2017, 76, 3054-3068. [CrossRef]

106. Mohammadi, L.; Bazrafshan, E.; Noroozifar, M.; Ansari-Moghaddama, A.R.; Khazaei Feizabad, A.R.; Mahvi, A.H. Optimization of the catalytic ozonation process using copper oxide nanoparticles for the removal of benzene from aqueous solutions. Glob. J. Environ. Sci. Manag. 2017, 3, 403-416.

107. Neppolian, B.; Choi, H.C.; Sakthivel, S.; Arabindoo, B.; Murugesan, V. Solar light induced and TiO2 assisted degradation of textile dye reactive blue 4 . Chemosphere 2002, 46, 1173-1181. [CrossRef]

108. Pirkanniemi, K.; Sillanpää, M. Heterogeneous water phase catalysis as an environmental application: A review. Chemosphere 2002, 48, 1047-1060. [CrossRef]

109. Klavarioti, M.; Mantzavinos, D.; Kassinos, D. Removal of residual pharmaceuticals from aqueous systems by advanced oxidation processes. Environ. Int. 2009, 35, 402-417. [CrossRef] [PubMed]

110. Fenton, H.J.H. LXXIII.-COxidation of tartaric acid in presence of iron. J. Chem. Soc. Trans. 1894, 65, 899-910. [CrossRef]

111. Mota, A.L.; Albuquerque, L.; Beltrame, L.; Chiavone-Filho, O.; Machulek, A.; Nascimento, C. Advanced oxidation processes and their application in the petroleum industry: A review. Braz. J. Pet. Gas 2009, 2.

112. Santos, M.S.F.; Alves, A.; Madeira, L.M. Paraquat removal from water by oxidation with Fenton's reagent. Chem. Eng. J. 2011, 175, 279-290. [CrossRef]

113. Peyton, G.R. Effect of bicarbonate alkalinity on performance of advanced oxidation processes. Water Res. Found. 1998.

114. Bhatnagar, A.; Cheung, H.M. Sonochemical Destruction of Chlorinated C1 and C2 Volatile Organic Compounds in Dilute Aqueous Solution. Environ. Sci. Technol. 1994, 28, 1481-1486. [CrossRef]

115. Shirgaonkar, I.Z.; Pandit, A.B. Sonophotochemical destruction of aqueous solution of 2,4,6-trichlorophenol. Ultrason. Sonochem. 1998, 5, 53-61. [CrossRef]

116. Compton, R.G.; Eklund, J.C.; Marken, F.; Rebbitt, T.O.; Akkermans, R.P.; Waller, D.N. Dual activation: Coupling ultrasound to electrochemistry-An overview. Electrochim. Acta 1997, 42, 2919-2927. [CrossRef]

117. Johnson, O.A.; Affam, A.C. Petroleum sludge treatment and disposal: A review. Environ. Eng. Res. 2019, 24, 191-201. [CrossRef]

118. Moussavi, G.; Khosravi, R.; Farzadkia, M. Removal of petroleum hydrocarbons from contaminated groundwater using an electrocoagulation process: Batch and continuous experiments. Desalination 2011, 278, 288-294. [CrossRef]

119. Islam, B. Petroleum sludge, its treatment and disposal: A review. Int. J. Chem. Sci. 2015, 13, 1584-1602.

120. Kong, S.-H.; Watts, R.J.; Choi, J.-H. Treatment of petroleum-contaminated soils using iron mineral catalyzed hydrogen peroxide. Chemosphere 1998, 37, 1473-1482. [CrossRef]

121. Yeh, C.K.-J.; Wu, H.-M.; Chen, T.-C. Chemical oxidation of chlorinated non-aqueous phase liquid by hydrogen peroxide in natural sand systems. J. Hazard. Mater. 2003, 96, 29-51. [CrossRef] 
122. Verma, S.; Prasad, B.; Mishra, I.M. Pretreatment of petrochemical wastewater by coagulation and flocculation and the sludge characteristics. J. Hazard. Mater. 2010, 178, 1055-1064. [CrossRef] [PubMed]

123. El Ashtoukhy, E.S.Z.; El-Taweel, Y.A.; Abdelwahab, O.; Nassef, E. Treatment of Petrochemical Wastewater Containing Phenolic Compounds by Electrocoagulation Using a Fixed Bed Electrochemical Reactor. Int. J. Electrochem. Sci. 2013, 8, 1534-1550.

124. Saeedi, M.; Khalvati-Fahlyani, A. Treatment of Oily Wastewater of a Gas Refinery by Electrocoagulation Using Aluminum Electrodes. Water Environ. Res. 2011, 83, 256-264. [CrossRef]

125. Wang, G.-D.; Li, Q.-J.; Luo, B.; Chen, X.-Y. Ex planta phytoremediation of trichlorophenol and phenolic allelochemicals via an engineered secretory laccase. Nat. Biotechnol. 2004, 22, 893-897. [CrossRef]

126. Singh, H.B.; Tabazadeh, A.; Evans, M.J.; Field, B.D.; Jacob, D.J.; Sachse, G.; Crawford, J.H.; Shetter, R.; Brune, W.H. Oxygenated volatile organic chemicals in the oceans: Inferences and implications based on atmospheric observations and air-sea exchange models. Geophys. Res. Lett. 2003, 30. [CrossRef]

127. Comba, M.E.; Kaiser, K.L.E. Suspended particulate concentrations in the St. Lawrence river (1985-1987) determined by centrifugation and filtration. Sci. Total Environ. 1990, 97-98, 191-206. [CrossRef]

128. Ramaswamy, B.; Kar, D.D.; De, S. A study on recovery of oil from sludge containing oil using froth flotation. J. Environ. Manag. 2007, 85, 150-154. [CrossRef] [PubMed]

129. Kim, D.K.; O'Shea, K.E.; Cooper, W.J. Oxidative degradation of alternative gasoline oxygenates in aqueous solution by ultrasonic irradiation: Mechanistic study. Sci. Total Environ. 2012, 430, 246-259. [CrossRef] [PubMed]

130. Haigh, S.D. A review of the interaction of surfactants with organic contaminants in soil. Sci. Total Environ. 1996, 185, 161-170. [CrossRef]

131. Petts, G.E.; Thoms, M.C.; Brittan, K.; Atkin, B. A freeze-coring technique applied to pollution by fine sediments in gravel-bed rivers. Sci. Total Environ. 1989, 84, 259-272. [CrossRef]

132. Azzouz, A.; Ballesteros, E. Combined microwave-assisted extraction and continuous solid-phase extraction prior to gas chromatography-mass spectrometry determination of pharmaceuticals, personal care products and hormones in soils, sediments and sludge. Sci. Total Environ. 2012, 419, 208-215. [CrossRef]

133. Lima, A.T.; Ottosen, L.M.; Heister, K.; Loch, J.P.G. Assessing PAH removal from clayey soil by means of electro-osmosis and electrodialysis. Sci. Total Environ. 2012, 435-436, 1-6. [CrossRef]

134. Chiang, H.-L.; Lin, K.-H.; Lai, N.; Shieh, Z.-X. Element and PAH constituents in the residues and liquid oil from biosludge pyrolysis in an electrical thermal furnace. Sci. Total Environ. 2014, 481, 533-541. [CrossRef]

135. Rijkenberg, M.J.A.; Depree, C.V. Heavy metal stabilization in contaminated road-derived sediments. Sci. Total Environ. 2010, 408, 1212-1220. [CrossRef]

136. Oller, I.; Malato, S.; Sánchez-Pérez, J.A. Combination of Advanced Oxidation Processes and biological treatments for wastewater decontamination-A review. Sci. Total Environ. 2011, 409, 4141-4166. [CrossRef]

137. Clutterbuck, B.; Yallop, A.R. Land management as a factor controlling dissolved organic carbon release from upland peat soils 2: Changes in DOC productivity over four decades. Sci. Total Environ. 2010, 408, 6179-6191. [CrossRef]

138. Lisk, D.J. Environmental effects of landfills. Sci. Total Environ. 1991, 100, 415-468. [CrossRef]

139. Juhasz, A.L.; Weber, J.; Stevenson, G.; Slee, D.; Gancarz, D.; Rofe, A.; Smith, E. In vivo measurement, in vitro estimation and fugacity prediction of PAH bioavailability in post-remediated creosote-contaminated soil. Sci. Total Environ. 2014, 473-474, 147-154. [CrossRef] [PubMed]

140. Wang, X.; Wang, Q.; Wang, S.; Li, F.; Guo, G. Effect of biostimulation on community level physiological profiles of microorganisms in field-scale biopiles composed of aged oil sludge. Bioresour. Technol. 2012, 111, 308-315. [CrossRef] [PubMed]

141. Carabineiro, S.A.C.; Chen, X.; Konsolakis, M.; Psarras, A.C.; Tavares, P.B.; Órfão, J.J.M.; Pereira, M.F.R.; Figueiredo, J.L. Catalytic oxidation of toluene on Ce-Co and La-Co mixed oxides synthesized by exotemplating and evaporation methods. Catal. Today 2015, 244, 161-171. [CrossRef]

142. Dziembaj, R.; Molenda, M.; Chmielarz, L.; Drozdek, M.; Zaitz, M.M.; Dudek, B.; Rafalska-Łasocha, A.; Piwowarska, Z. Nanostructured Cu-Doped Ceria Obtained by Reverse Microemulsion Method as Catalysts for Incineration of Selected VOCs. Catal. Lett. 2010, 135, 68-75. [CrossRef]

143. Tang, W.; Wu, X.; Liu, G.; Li, S.; Li, D.; Li, W.; Chen, Y. Preparation of hierarchical layer-stacking Mn-Ce composite oxide for catalytic total oxidation of VOCs. J. Rare Earths 2015, 33, 62-69. [CrossRef] 
144. Ward, O.; Singh, A.; Van Hamme, J. Accelerated biodegradation of petroleum hydrocarbon waste. J. Ind. Microbiol. Biotechnol. 2003, 30, 260-270. [CrossRef]

145. Aivalioti, M.; Vamvasakis, I.; Gidarakos, E. BTEX and MTBE adsorption onto raw and thermally modified diatomite. J. Hazard. Mater. 2010, 178, 136-143. [CrossRef]

146. Sangkhun, W.; Laokiat, L.; Tanboonchuy, V.; Khamdahsag, P.; Grisdanurak, N. Photocatalytic degradation of BTEX using W-doped TiO2 immobilized on fiberglass cloth under visible light. Superlattices Microstruct. 2012, 52, 632-642. [CrossRef]

147. Hubbard, H.F.; Coleman, B.K.; Sarwar, G.; Corsi, R.L. Effects of an ozone-generating air purifier on indoor secondary particles in three residential dwellings. Indoor Air 2005, 15, 432-444. [CrossRef]

148. Doran, G.F.; Carini, F.H.; Fruth, D.A.; Drago, J.A.; Leong, L.Y.C. Evaluation of Technologies to Treat Oil Field Produced Water to Drinking Water or Reuse Quality. In SPE Annual Technical Conference and Exhibition; Society of Petroleum Engineers: San Antonio, TX, USA, 1997; p. 12.

149. Mousa, K.M.; Hadi, H.J. Coagulation/Flocculation Process for Produced Water Treatment. 2016. Available online: http://inpressco.com/category/ijcet (accessed on 15 February 2020).

150. Kriipsalu, M.; Marques, M.; Maastik, A. Characterization of oily sludge from a wastewater treatment plant flocculation-flotation unit in a petroleum refinery and its treatment implications. J. Mater. Cycles Waste Manag. 2008, 10, 79-86. [CrossRef]

151. Bellamy, W.D.; Hickman, G.T.; Mueller, P.A.; Ziemba, N. Treatment of VOC-Contaminated Groundwater by Hydrogen Peroxide and Ozone Oxidation. Res. J. Water Pollut. Control Fed. 1991, 63, 120-128.

152. Fadaei, S.; Moghadam, F.N.; Hashemi, M.H.P. BTEX Removal from Aqueous Solution by Modified Multi-Walled Carbon Nanotubes With Ozone. Anu. Inst. Geocienc. 2017, 40, 235-242. [CrossRef]

153. Mohammadi, L.; Bazrafshan, E.; Noroozifar, M.; Ansari-Moghaddam, A. Application of Heterogeneous Catalytic Ozonation Process with Magnesium Oxide Nanoparticles for Toluene Degradation in Aqueous Environments. Health Scope 2016, 5, e40439. [CrossRef]

154. Asgari, G.; Mohammadi, A.S.; Mortazavi, S.B.; Ramavandi, B. Investigation on the pyrolysis of cow bone as a catalyst for ozone aqueous decomposition: Kinetic approach. J. Anal. Appl. Pyrolysis 2013, 99, 149-154. [CrossRef]

155. Veiga, M.C.; Fraga, M.; Amor, L.; Kennes, C. Biofilter performance and characterization of a biocatalyst degrading alkylbenzene gases. Biodegradation 1999, 10, 169-176. [CrossRef] [PubMed]

156. Lu, C.; Lin, M.-R.; Chu, C. Effects of $\mathrm{pH}$, moisture, and flow pattern on trickle-bed air biofilter performance for BTEX removal. Adv. Environ. Res. 2002, 6, 99-106. [CrossRef]

157. Berenjian, A.; Chan, N.; Malmiri, H.J. Volatile organic compounds removal methods, a review. Am. J. Biochem. Biotechnol. 2012, 8, 220-229.

158. Benatti, C.T.; Tavares, C.R.G.; Guedes, T.A. Optimization of Fenton's oxidation of chemical laboratory wastewaters using the response surface methodology. J. Environ. Manag. 2006, 80, 66-74. [CrossRef]

159. Kang, Y.W.; Hwang, K.-Y. Effects of reaction conditions on the oxidation efficiency in the Fenton process. Water Res. 2000, 34, 2786-2790. [CrossRef]

160. Yang, C.; Chen, H.; Zeng, G.; Yu, G.; Luo, S. Biomass accumulation and control strategies in gas biofiltration. Biotechnol. Adv. 2010, 28, 531-540. [CrossRef] [PubMed]

161. Deeb, R.A.; Alvarez-Cohen, L. Temperature effects and substrate interactions during the aerobic biotransformation of BTEX mixtures by toluene-enriched consortia and Rhodococcus rhodochrous. Biotechnol. Bioeng. 1999, 62, 526-536. [CrossRef]

162. Hwang, S.-C.J.; Wu, S.-J.; Lee, C.-M. Water Transformation in the Media of Biofilters Controlled by Rhodococcus fascians in Treating an Ethyl Acetate-Contaminated Airstream. J. Air Waste Manag. Assoc. 2002, 52, 511-520. [CrossRef] [PubMed]

163. Leili, M.; Mousavi, S.R.; Nadafi, K.; Ghaffari, M. The investigation of single ozonation process, catalytic ozonation process and single adsorption on activated carbon efficienciesfor removal of furfural from aqueous solution. J. Sabzevar Univ. Med. Sci. 2013, 20, 51-61.

164. Church, J.; Lundin, J.G.; Diaz, D.; Mercado, D.; Willner, M.R.; Lee, W.H.; Paynter, D.M. Identification and characterization of bilgewater emulsions. Sci. Total Environ. 2019, 691, 981-995. [CrossRef] [PubMed]

165. Ríos, G.; Pazos, C.; Coca, J. Destabilization of cutting oil emulsions using inorganic salts as coagulants. Colloids Surf. A Physicochem. Eng. Asp. 1998, 138, 383-389. [CrossRef] 
166. Kulmyrzaev, A.; Chanamai, R.; McClements, D.J. Influence of $\mathrm{pH}$ and $\mathrm{CaCl} 2$ on the stability of dilute whey protein stabilized emulsions. Food Res. Int. 2000, 33, 15-20. [CrossRef]

167. Mitra, R.K.; Paul, B.K. Effect of temperature and salt on the phase behavior of nonionic and mixed nonionic-ionic microemulsions with fish-tail diagrams. J. Colloid Interface Sci. 2005, 291, 550-559. [CrossRef]

168. Asselin, M.; Drogui, P.; Brar, S.K.; Benmoussa, H.; Blais, J.F. Organics removal in oily bilgewater by electrocoagulation process. J. Hazard. Mater. 2008, 151, 446-455. [CrossRef]

169. Santisi, S.; Gentile, G.; Volta, A.; Bonsignore, M.; Mancini, G.; Quatrini, P.; Capello, S. Isolation and characterization of oil degrading bacteria from bilge water. Int. J. Microbiol. Appl. 2015, 2, 45-49.

170. McMillen, S.J.; Magaw, R.I.; Kerr, J.M.; Sweeney, R.E.; Nakles, D.V.; Geiger, S.C. A new risk based approach to establish clean up levels for total petroleum hydrocarbon. In Proceedings of the 6 th International Petroleum Environmental Conference, Houston, TX, USA, 16-18 November 1999; Sublette, K.L., Ed.; SCG, Inc.: Tulsa, OK, USA, 2000; pp. 438-459.

171. Kuyukina, M.S.; Krivoruchko, A.V.; Ivshina, I.B. Advanced Bioreactor Treatments of Hydrocarbon-Containing Wastewater. Appl. Sci. 2020, 10, 831. [CrossRef]

172. Gomes, H.T.; Samant, P.V.; Serp, P.; Kalck, P.; Figueiredo, J.L.; Faria, J.L. Carbon nanotubes and xerogels as supports of well-dispersed Pt catalysts for environmental applications. Appl. Catal. B Environ. 2004, 54, 175-182. [CrossRef]

173. Lu, C.; Su, F.; Hu, S. Surface modification of carbon nanotubes for enhancing BTEX adsorption from aqueous solutions. Appl. Surf. Sci. 2008, 254, 7035-7041. [CrossRef]

174. Aivalioti, M.; Papoulias, P.; Kousaiti, A.; Gidarakos, E. Adsorption of BTEX, MTBE and TAME on natural and modified diatomite. J. Hazard. Mater. 2012, 207-208, 117-127. [CrossRef]

175. Daifullah, A.A.M.; Girgis, B.S. Impact of surface characteristics of activated carbon on adsorption of BTEX. Colloids Surf. A Physicochem. Eng. Asp. 2003, 214, 181-193. [CrossRef]

176. Su, F.; Lu, C.; Hu, S. Adsorption of benzene, toluene, ethylbenzene and p-xylene by NaOCl-oxidized carbon nanotubes. Colloids Surf. A Physicochem. Eng. Asp. 2010, 353, 83-91. [CrossRef]

177. Ji, G.D.; Sun, T.H.; Ni, J.R.; Tong, J.J. Anaerobic baffled reactor (ABR) for treating heavy oil produced water with high concentrations of salt and poor nutrient. Bioresour. Technol. 2009, 100, 1108-1114. [CrossRef]

178. Rastegar, S.O.; Mousavi, S.M.; Shojaosadati, S.A.; Sheibani, S. Optimization of petroleum refinery effluent treatment in a UASB reactor using response surface methodology. J. Hazard. Mater. 2011, 197, $26-32$. [CrossRef]

179. Hayder, G.; Kutty, S.R.M.; Isa, M.H.; Lemma, T.A. Optimization of Anaerobic Treatment of Petroleum Refinery Wastewater Using Artificial Neural Networks. Res. J. Appl. Sci. Eng. Technol. 2013, 6, 2077-2082.

180. Zheng, T. A compact process for treating oilfield wastewater by combining hydrolysis acidification, moving bed biofilm, ozonation and biologically activated carbon techniques. Environ. Technol. 2016, 37, 1171-1178. [CrossRef]

181. Huo, S.; Zhu, F.; Zou, B.; Xu, L.; Cui, F.; You, W. A two-stage system coupling hydrolytic acidification with algal microcosms for treatment of wastewater from the manufacture of acrylonitrile butadiene styrene (ABS) resin. Biotechnol. Lett. 2018, 40, 689-696. [CrossRef] [PubMed]

182. Huo, S.; Chen, J.; Chen, X.; Wang, F.; Xu, L.; Zhu, F.; Guo, D.; Li, Z. Advanced treatment of the low concentration petrochemical wastewater by Tribonema sp. microalgae grown in the open photobioreactors coupled with the traditional Anaerobic/Oxic process. Bioresour. Technol. 2018, 270, 476-481. [CrossRef] [PubMed]

183. Wang, S.; Ghimire, N.; Xin, G.; Wakjera, E.; Bakke, R. Efficient high strength petrochemical wastewater treatment in a hybrid vertical anaerobic biofilm (HyVAB) reactor: A pilot study. Water Pract. Technol. 2017, 12, 501-513. [CrossRef]

184. Janka, E.; Carvajal, D.; Wang, S.; Bakke, R.; Dinamarca, C. Treatment of Metformin-Containing Wastewater by a Hybrid Vertical Anaerobic Biofilm-Reactor (HyVAB). Int. J. Environ. Res. Public Health 2019, 16, 4125. [CrossRef]

(C) 2020 by the authors. Licensee MDPI, Basel, Switzerland. This article is an open access article distributed under the terms and conditions of the Creative Commons Attribution (CC BY) license (http://creativecommons.org/licenses/by/4.0/). 